\title{
Multiscale patterns in the diversity and organization of benthic intertidal fauna among French Atlantic estuaries
}

Hugues Blanchet ${ }^{\mathrm{a}, *}$, Benoît Gouillieux ${ }^{\mathrm{a}}$, Sandrine Alizier ${ }^{\mathrm{b}}$, Jean-Michel Amouroux ${ }^{\mathrm{c}}$, Guy Bachelet ${ }^{\mathrm{a}}$, Anne-Laure Barilléd, Jean-Claude Dauvin ${ }^{b, e}$, Xavier de Montaudouin ${ }^{a}$, Valérie Derolez $^{\dagger}$ Nicolas Desroy ${ }^{g}$, Jacques Grall ${ }^{\mathrm{h}}$, Antoine Grémare ${ }^{\mathrm{a}}$, Pascal Hacquebart', Jérôme Jourde ${ }^{\mathrm{h}, j}$, Céline Labrune ${ }^{c}$, Nicolas Lavesque ${ }^{a}$, Alain Meirland ${ }^{k}$, Thiebaut Nebout ${ }^{9}$, Frédéric Olivier', Corine Pelaprat $^{m}$, Thierry Ruellet ${ }^{b, k}$, Pierre-Guy Sauriau ${ }^{j}$, Sébastien Thorin ${ }^{n}$

\footnotetext{
a Université de Bordeaux, CNRS, UMR 5805 EPOC, Station Marine d'Arcachon, 2 Rue du Professeur Jolyet, 33120 Arcachon, France

' Université de Lille 1, CNRS, UMR LOG 8187, Station Marine de Wimereux, 28 Avenue Foch, BP 80, 62930 Wimereux, France

c Université Paris 6, CNRS, UMR 8222 LECOB, Laboratoire Arago, 66650 Banyuls-sur-Mer, France

${ }^{d}$ Bio-Littoral, Laboratoire Mer Molécule Santé, Université de Nantes, France

e Université de Caen Basse-Normandie, CNRS, UMR 6143 M2C, Laboratoire Morphodynamique Continentale et Côtière, 2-4 Rue des Tilleuls, 14000 Caen, France

${ }^{\dagger}$ IFREMER LER/LR, Avenue Jean Monnet, BP 171, 34203 Sète Cedex, France

${ }^{9}$ IFREMER LER Finistère-Bretagne Nord, Station de Dinard, 38 Rue du Port Blanc, BP 80108, 35801 Dinard, France

${ }^{\mathrm{h}}$ Institut Universitaire Européen de la Mer, UMS 3113, Technopôle Brest-Iroise, Rue Dumont d'Urville, 29280 Plouzané, France

' GEMEL Groupe d'Étude des Milieux Estuariens et Littoraux - Equipe Normandie, Station Marine, Centre Régional d'Etudes Côtières, 54 Rue du Docteur Charcot, 14530 Luc-sur-Mer, France

j Université de La Rochelle, CNRS, UMR 7266 LIENSs, 2 Rue Olympe de Gouges, 17000 La Rochelle, France

${ }^{k}$ GEMEL Groupe d'Étude des Milieux Estuariens et Littoraux - Equipe Picardie, 115 Quai Jeanne d'Arc, 80230 Saint-Valéry-sur-Somme, France

'Muséum National d'Histoire Naturelle, UMR BOREA, DMPA, 61 Rue Buffon, 75005 Paris, France

${ }^{m}$ Stareso, Pointe Revellata, BP 33, 20260 Calvi, France

${ }^{n}$ CREOCEAN, Zone Technocean, Rue Charles Tellier, 17000 La Rochelle, France
}

\author{
*: Corresponding author: Hugues Blanchet, tel.: + 33556223935 ; fax: + 33556840848 ; \\ email address : $\underline{\text { h.blanchet@epoc.u-bordeaux1.fr }}$
}

\begin{abstract}
:
Based on a parallel sampling conducted during autumn 2008, a comparative study of the intertidal benthic macrofauna among 10 estuarine systems located along the Channel and Atlantic coasts of France was performed in order to assess the level of fauna similarity among these sites and to identify possible environmental factors involved in the observed pattern at both large (among sites) and smaller (benthic assemblages) scales. More precisely this study focused on unraveling the observed pattern of intertidal benthic fauna composition and diversity observed at among-sites scale by exploring both biotic and abiotic factors acting at the among- and within-site scales. Results showed limited level of similarity at the among-site level in terms of intertidal benthic fauna composition and
\end{abstract}


diversity. The observed pattern did not fit with existing transitional water classification methods based on fish or benthic assemblages developed in the frame of the European Water Framework Directive (WFD). More particularly, the coastal plain estuaries displayed higher among-sites similarity compared to ria systems. These coastal plain estuaries were characterized by higher influence of river discharge, lower communication with the ocean and high suspended particulate matter levels. On the other hand, the ria-type systems were more dissimilar and different from the coastal plain estuaries. The level of similarity among estuaries was mainly linked to the relative extent of the intertidal "Scrobicularia planaCerastoderma edule" and "Tellina tenuis" or "Venus" communities as a possible consequence of salinity regime, suspended matter concentrations and fine particles supply with consequences on the trophic functioning, structure and organization of benthic fauna. Despite biogeographical patterns, the results also suggest that, in the context of the WFD, these estuaries should only be compared on the basis of the most common intertidal habitat occurring throughout all estuarine systems and that the EUNIS biotope classification might be used for this purpose. In addition, an original inverse relation between $\mathrm{y}$-diversity and area was shown; however, its relevance might be questioned.

\section{Highlights}

- In the WFD context benthic fauna among estuaries have to be compared in order to assess their quality status. Intertidal benthic macrofauna was compared among 10 estuaries at two scales: whole estuary scale and benthic habitats-scale. Benthic fauna mainly differed between coastal plain estuaries and ria-type estuaries. It was mainly linked to the relative extent of two different benthic communities/habitats. We can only compare estuaries using the most common of these community.

Keywords : estuaries ; Macrozoobenthos ; Diversity ; structuring factors ; WFD 


\section{Introduction}

Elliott and Whitfield (2011) defined estuaries as "semi-enclosed coastal bodies of water which are connected to the sea either permanently or periodically, have a salinity that is different from the adjacent open ocean due to freshwater inputs, and include a characteristic biota". According to this definition, estuaries should display a characteristic benthic fauna. Benthic organisms are recognized as good indicators of environmental conditions mainly because of (1) their mostly sedentary life as adults, preventing them from escaping changing conditions, and (2) their position at the sedimentwater-column interface, allowing them to integrate variations of both sub-systems (Dauvin, 1993). Most estuaries are indeed characterized by a very limited number of benthic species which number decreases as water salinity decreases (Remane, 1934; Remane and Sclieper, 1958). The scheme proposed by Remane (1934), describing the succession of marine, brackish and freshwater species along the salinity gradient in the Baltic Sea has been increasingly criticized (Barnes, 1989; Attrill and Rundle, 2002) and recently reviewed by Whitfield et al. (2012). One of the main objections to this schematic diagram is the existence of truly "brackish species" that are supposed to exclusively dwell within estuaries. Based on works conducted along the full salinity gradient within estuarine systems (e.g. Attrill and Rundle, 2002; Rodrigues et al., 2011), there is no evidence of the existence of purely brackish benthic species (Whitfield et al., 2012 and references therein). Nevertheless, a pool of typically estuarine species can be recognized. This pool of species would consist in marine euryhaline species that can live in fully marine conditions. These species however display higher occurrence, abundance and biomass levels in estuarine conditions as the abundance of more stenohaline species decreases with decreasing average level of salinity (Little, 2000; Attrill, 2002). The other main objection to the Remane's scheme is the probably most important consequences of the variability in salinity conditions than the salinity level by itself (Attrill, 2002). Nevertheless, the pattern of increasing abundance and occurrence of typically estuarine species within estuaries compared to fully marine conditions may be explained by the progressive disappearance of more competitive, but more stenohaline, species towards the head of an estuary allowing the increase of populations of typically estuarine, more euryhaline, species as they are released from interspecific competition (Little, 2000). As the salinity decreases toward the head of an estuary, typically estuarine marine species reach their tolerance limit and disappear, leading to the generally observed decrease of marine benthic species number from the downstream to the upstream areas. The particularity of these typically estuarine benthic species has lead to define them as opportunists since they only show high occurrence and abundance levels when other species disappear and they are typically retrieved in areas with very low species number. These very features of estuarine benthic fauna have lead to considerable difficulties when applying ecological quality bio-evaluation methodologies based on benthic macrofauna to estuarine systems (Elliott and Quintino, 2007; Blanchet et al., 2012). The need of appropriate methodologies to evaluate the ecological quality of European estuarine water bodies has been urged since the publication of the European Water Framework Directive (WFD). One of the main difficulties 
in estuarine systems is to determine appropriate reference conditions which should correspond to pristine environmental conditions. Several proposals have been made by classifying transitional water bodies into types (e.g. Barbone et al., 2012). For instance Borja et al. (2004b) used the WFDclassification to derive theoretical reference conditions for the benthos of each type of water body. More recently, Galván et al. (2010) proposed another classification of transitional water bodies with the same objective i.e. defining reference conditions for each type of estuary. The latter authors however recognized, in accordance with a growing number of studies, that benthic conditions varied greatly at finer scale within estuarine systems (Bald et al., 2005; de Paz et al., 2008; Rodrigues et al., 2011).

Given the characteristics of the typical estuarine benthic fauna and the challenges of ecological quality assessment in estuarine transitional waters, it is still necessary to evaluate the level of similarity of benthic fauna at both the among-whole estuaries scale and at the scale of similar habitat among different estuaries. In other words: are estuarine ecosystems (or estuarine ecosystem-types) comparable in terms of benthic fauna at the scale of the whole system or at least, at the scale of similar habitat among estuaries? Our study thus focused on comparing the intertidal estuarine fauna of ten estuarine systems located along the French Atlantic-Channel coast in order (1) to assess the degree of fauna similarity among estuarine systems along the French coasts and to relate observed differences to relevant physical features at the among-sites scale. The results obtained will allow to evaluate the accuracy of existing typologies developed for the WFD. The second objective was (2) to relate the pattern observed at the among-sites scale to finer (within-site) scale organization of benthic macrofauna and associated environmental factors. This will allow to evaluate the possibility of comparing estuarine benthic fauna among sites at a finer, biotope-scale (Ducrotoy, 2010). 


\section{Material and methods}

\subsection{Study area}

The study focused on ten estuarine ecosystems located along the French coast (Fig. 1). This study included the three largest French estuaries (with surface area $>190 \mathrm{~km}^{2}$ : Gironde (Gir), Loire (Loi) and Seine (Sei)) together with seven smaller estuarine systems ranging in size from $56.6 \mathrm{~km}^{2}$ Aiguillon Sèvre Niortaise (Aig) to less than $3 \mathrm{~km}^{2}$ (Belon (Bel) and Bidassoa (Bid)). All estuaries were influenced by tide which ranged from macrotidal to hypertidal systems (Table 1). The downstream and upstream delimitations of estuaries corresponded to the limits of water bodies defined within the European Water Framework Directive (WFD).

\subsection{Physical descriptors}

Total area of each estuary was retrieved from the WFD-map using ARCGIS 9. Intertidal areas were obtained from the literature including Nicolas et al. (2010). In order to assess resemblance among the ten sites and to relate observed patterns to general hydrological, morphological or sedimentary features of the study sites, several hydro-morphological indices were used. Average river discharge values were retrieved for the October 2007 - October 2008 period from the French water information system database (http://www.hydro.eaufrance.fr/) and from the Centro de Estudios Hidrográficos (http://hercules.cedex.es/general/default.htm) or from literature in case of missing data. Estimate of estuarine water volume at high tide (V) was computed as the sum of estuarine water volume at low tide and tidal prism (TP). Estuarine water volume at low tide was obtained from average channel depth estimates based on available depth measures, marine maps or published data (Valencia et al., 2004) and site areas (Hume et al., 2007). Tidal prism (TP) was estimated using the average tidal height (difference $\mathrm{H}$ of water height between low and high tide during an average tide) at the vicinity of each site using chart datum and the intertidal area of each site (Aint). The tidal prism was thus computed as H $\times 0.5 \times$ Aint (Hume et al., 2007). Following Hume et al. (2007) and Galván et al. (2010), ratios between tidal prism and estuarine water volume at high tide (TP:V ratio) and between average river discharge during a 12 hours tidal cycle $(\mathrm{R})$ and estuarine water volume at high tide (R:V ratio) were computed, as well as the ratio TP:R. Since these values only corresponded to estimates, all values were corrected to the nearest $10^{5} \mathrm{~m}^{3}$. Three descriptors of the morphology of the systems were used: EE (TWEI in Galván et al. (2010)), which is an index reflecting the system elongation; SC (TWCI in Galván et al. (2010)), an index describing the morphological complexity of the system; and CI, which reflects the more or less closed character of the system. Details concerning the computation of these indices can be found in the works of Hume et al. (2007) and Galván et al. (2010). The average river slope was computed as the ratio between the main rivers source elevation (in $\mathrm{m}$ ) and the length of the river to the mouth of the estuary (in $\mathrm{km}$ ). Average SPM levels (Suspended Particulate Matter concentrations) were retrieved from published or unpublished data. The main type of sediments occurring in the different estuarine systems was calculated as the median value of grain-size measured 
(SED, in $\Phi$-unit) at each sampled station. The variability of sediment types within each site was estimated as the coefficient of variation associated to the mean (in \%). Sediments were sampled at each station. The sediment samples were sieved through a series of meshes of decreasing aperture which allowed to determine the sediment grain-size distribution. Sediment types were defined based on the logic chart for assigning textural classes to sediments proposed by Farrel et al. (2012) while retaining only the following sediment types: CS (coarse sediments, corresponding to gravelly sediments and coarser sediments (Farrel et al., 2012)), S (sand), mS (muddy sand), sM (sandy mud) and $M$ (mud). The relative position of each station along the estuarine gradient of each site was computed as the ratio between the distance from each station to the most downstream station and the distance from the most downstream to the most upstream station following the thalweg.

\subsection{Biological data}

Intertidal soft-bottom macrofauna was collected in autumn 2008 in ten estuaries (Fig. 1). The sampling strategy consisted in sampling stations regularly distributed along the downstream-upstream axis of the estuarine systems while restricting to the poly- and mesohaline zones. Sampling stations were located on the mid to low levels of the intertidal area. All stations corresponded to bare sediments. Since stations were regularly distributed along the estuarine axis, some stations may correspond to areas potentially perturbed by human activities. In this case, the station was sampled and the potential perturbation was included in the metadata. The sampling procedure consisted in collecting a total area of $0.2 \mathrm{~m}^{2}$ per station using several replicated samples. This was achieved by pooling two $0.1 \mathrm{~m}^{2}$ grab samples in site where access to intertidal areas was too dangerous (Aiguillon-Sèvre niortaise, Charente, Loire and Trieux estuaries) or by pooling 5 to 10 core samples (depending on core dimensions) in areas where the intertidal area could be accessed by foot (Belon ( 5 samples), Bidassoa and Gironde (7), Orne, Seine, Some (10)). The sampling effort (i.e., the number of stations) was higher in the three largest estuaries than in the smaller sites (Table 1). All samples were sieved through a 1-mm mesh. The remaining fraction was preserved in $4 \%$ formalin and stained with Rose Bengal. Analysis of fauna was performed in the laboratory where individuals were identified to species level, when possible, and counted. All data collected were organized in a single database.

\subsection{Data analyses.}

\subsubsection{Database management.}

Prior to the analysis of data, the level of identification of taxa was homogenized throughout the database and the small sessile epifauna taxa (spirorbid and serpulid polychaetes, barnacles) were excluded because there were only few specimens fixed on boulders and shells collected in the softbottom habitats. Abundance data were first $\log _{\mathrm{e}}$-transformed in order to balance the numerical dominance of some particularly abundant taxa such as Peringia ulvae or oligochaetes. Similarity matrices between stations were then computed using the Bray-Curtis similarity coefficient (Clarke and Gorley, 2006). 


\subsubsection{Comparison of benthic fauna at the among-sites scale and relation to physical characteristics}

Statistically significant difference in benthic fauna among estuaries was tested by one-way PERMANOVA performed on the Bray-Curtis similarity matrix using 'sites' as factor (Anderson et al., 2008). In case of significant difference, pairwise tests were conducted to assess differences between each pair of sites. In order to evaluate the degree of fauna similarity among sites and to relate the observed pattern to hydromorphological variables, a measure of average fauna similarity among sites was first obtained by computing a matrix of distances among site centroids based on the amongstations Bray-Curtis similarity matrix. The among-sites matrix was obtained using the 'distance among centroids' procedure provided by PRIMER with PERMANOVA+ package (Anderson et al., 2008). This procedure consisted in calculating a resemblance matrix among site centroids in the space of the Bray-Curtis similarity measure. Ordinations of site centroids were visualized using Principal Coordinates analysis (PCO) and a cluster analysis was performed in order to provide a classification of sites. The obtained classification and ordination were compared to three available typologies issued from (1) the WFD-classification, (2) the fish-based classification of North European estuaries proposed by Nicolas et al. (2010), and (3) the benthos-based typology of transitional water bodies developed by Galván et al. (2010) for cantabrian coastal water bodies. Relation between observed pattern of macrofauna and physical variables was investigated through the BEST procedure (Clarke and Gorley, 2006). This procedure permitted to identify the main hydrological or morphological variables which together displayed the highest level of (rank-) correlation with the distances among centroid matrix. Prior to the BEST analysis, a selection of variables was operated by selecting among variables displaying high level of Spearman rank correlation coefficient $(\geq 0.7$, disregarding the sign of the coefficient).

Macrobenthic diversity in the ten estuaries was compared using the three components of diversity, namely $\alpha$-, $\beta$ - and $\gamma$-diversity. $\operatorname{Gamma}(\gamma)$-diversity is the number of species at the scale of a large area (e.g. an estuary) whereas $\alpha$-diversity is the number of species at smaller scale, typically in a collection of samples from one station or one habitat (Gray, 2000; Maguran, 2004). The $\gamma$-diversity at the scale of each site (one of the ten estuaries studied here) was calculated as the total number of taxa recorded in one site (by pooling all stations from a given site). Since this total number of taxa varies as a function of the sampling effort (number of stations), $\gamma$-diversity among site was compared using the same number of stations (10 stations, corresponding to a sampled area of $2 \mathrm{~m}^{2}$ ). In sites where more than 10 stations were sampled, the average total number of taxa in all combination of 10 stations combined was used as estimate of $\gamma$-diversity. This was made possible by computing the species-accumulation curves for each estuary. These species accumulation curves were obtained by randomizing the order of samples (999 permutations) using PRIMER software. The level of $\gamma$-diversity obtained was compared to available data from other North European estuarine intertidal areas by retrieving this information 
from published data obtained with a comparable sampling effort (measured as total sampled area, in $\mathrm{m}^{2}$ ). As much as possible, the number of species published was reduced to obtain a similar level of taxonomic level of identification as used in our analysis. For instance, oligochaetes or insects identified to species or family-levels were pooled into one taxon; nematodes, foraminifers, ostracods and small sessile organisms mainly related to the presence of hard substrates (spirorbids, barnacles) were not considered. The obtained number of taxa and corresponding sampled area were plotted together with the species-accumulation curves obtained for each of the ten sites studied. Observed differences in $\gamma$-diversity among studied sites were correlated with physical variables at the site-scale by way of Spearman rank correlation coefficient. Compared using a similar sampling effort, the total number of taxa in a site is dependent on the two components of diversity, namely $\alpha$-diversity which is the number of taxa in a given station $\left(0.2 \mathrm{~m}^{2}\right)$, and the variation in the identities of species among stations ( $\beta$-diversity). In order to measure $\beta$-diversity, the classical Whittaker beta diversity index $\beta_{\mathrm{w}}$ was computed as the ratio between the total number of taxa in a given site ( $\gamma$-diversity) and the number of taxa in a given station from the same site ( $\alpha$-diversity). This index gave a measure of how much, on average, a whole site was richer than its stations. This index of $\beta$-diversity was used in order to give an overview of the general level of $\beta$-diversity variations; however, other complementary methodologies can be used giving more insight on the patterns of $\beta$-diversity (Maguran, 2004; and recent reviewed by Anderson et al., 2011). The number of taxa per station $\left(0.2 \mathrm{~m}^{2}\right)$ was used as the measure of $\alpha$-diversity. Difference in the level of $\alpha$-diversity among sites was assessed by PERMANOVA and pairwise tests. Finally, in order to compare the relative contribution of $\beta$-diversity on $\gamma$-diversity among sites, $\gamma$ diversity was plotted against average $\alpha$-diversity measured in each site. The resulting plot should be more of less linear given the multiplicative relation between the different components of diversity $(\gamma=\beta \times \alpha)$ (Maguran, 2004). Site-specific discrepancy from this fitted linear model could hence be interpreted as difference in $\beta$-diversity: higher $\beta$-diversity if the point lays over the fitted line, higher $\beta$-diversity if the point lies below the fitted line or similar level of $\beta$-diversity if the point is close to the fitted line. The linearity of this relation and the overall discrepancy from linearity was measured using Pearson's coefficient of linear correlation.

In order to put in evidence differences in the functioning of the benthic food web among estuaries, the abundance of species within trophic groups was compared. Species were classified into five trophic groups: subsurface deposit feeders (SSDF; taxa feeding head-down from bulk organic matter within the sediment), interface feeders (IF; species also known as 'surface deposit feeders' that feed from organic matter at the sediment surface and that usually can also shift to suspension feeding), suspension feeders (SF; taxa feeding mainly on suspended organic matter), grazers/herbivores (G; species mainly feeding from microphytobenthos from surface sediments and/or from angiosperm leaves and/or directly from angiosperms or macroalgae), and carnivores and omnivores (C-O; species which include fauna as a substantial part of their diet). This classification was established from 
literature (Fauchald and Jumars, 1979; Bachelet, 1981; Sauriau et al., 1989; Hily and Bouteille, 1999), available information on WORMS (www.marinespecies.org) and/or unpublished results obtained through stable isotope data. Since the study of Tenore et al. (2006) showed that the total number of taxa within different functional groups of macrofauna could be linked to the morphology of coastal and estuarine systems, we accordingly considered this total number of taxa within the different trophic groups as indicators of each site characteristics. Hence, the total number of taxa from each trophic group and each site was compared on the basis of a similar sampled area. This was obtained by computing the species accumulation curves for each trophic group and each site. All species accumulation curves were obtained by randomizing the order of samples (999 permutations) using PRIMER software.

\subsubsection{Benthic fauna and structuring environmental variables at the within-site scale}

Benthic assemblages were determined using hierarchical classification of stations through cluster analysis by group-average method performed on the among-stations Bray-Curtis similarity matrix. The resulting dendrogram was investigated at three levels of increasing similarity: $10 \%, 20 \%$ and $30 \%$. The relevance of the station groups obtained was evaluated by the SIMPROF procedure. This procedure performed a series of similarity profile permutation tests at each node of the dendrogram (Clarke and Gorley, 2006). At each node of the dendrogram, a test of the null hypothesis that the set of samples to be divided did not differ in multivariate structure was performed. This procedure hence permitted to decide whether further subdivision within a group of stations clustering at e.g. $10 \%$ similarity level was relevant at e.g. $20 \%$ similarity level.

Since our objective was to evaluate the relative influence of salinity and sediment type in structuring macrofauna within each estuary, the further set of analyses was performed separately for each site. Two proxies were used to evaluate the importance of both factors within one site: (1) the relative position of each station along the estuarine gradient of each site, which was computed as the ratio between the distance from each station to the most downstream station and the distance from the most downstream to the most upstream station following the thalweg (\% downstream), and (2) sediment grain-size in $\Phi$ units (Grain-size). The relative position of each station along the estuarine axis was expressed as a percentage and was expected to be correlated to the relative level of salinity occurring from the lower to the upper reaches of the investigated area. This proxy was preferred to punctual measures of salinity because, in an estuary, a one-time measure of salinity is not relevant to establish the real salinity conditions (average level and variations) occurring at one station in the course of seasons (fluctuations of river discharges), months (spring tide $v s$ neap tide) or days (high tide $v s$ low tide).

The influence of each of the two variables on the structure of macrofauna was determined by the DISTLM method which consists in partitioning the variation in the data described by the Bray-Curtis similarity matrix using simple or multiple regression models (Anderson et al., 2008). This permitted to evaluate the proportion of variation in among-samples similarity explained by each of the two 
variables separately and in linear combination. In addition to this procedure, the level of correlation between both variables was measured by Spearman rank correlation coefficient.

The pattern of $\alpha$-diversity within each estuary was described by non-parametric Spearman's rank correlation coefficient with environmental variables (Siegel, 1956). 


\section{Results}

\subsection{Among-sites comparisons}

\subsubsection{Benthic macrofauna composition and associated environmental factors}

A total of 172 taxa were recorded for the intertidal macrofauna of the ten estuaries studied. Among these taxa, only 4 taxa were identified in all estuaries, namely Hediste diversicolor, Cerastoderma edule, Scrobicularia plana and oligochaetes. Only $15 \%$ of the taxa were recorded in at least half the studied sites and more than 50\% were recorded in a single site. Among sites, the Belon and Bidassoa estuaries displayed the largest proportion of unique taxa (taxa that were present in a single site) with about 2/5 of their total number of taxa as unique. In contrast, the Seine and Loire estuaries displayed the lowest proportion (less than 5\%) of unique taxa, while the other estuaries displayed between $1 / 4$ (Trieux estuary) and 1/10 (Aiguillon-Sèvre Niortaise, Orne estuary) of their taxa as unique.

PERMANOVA indicated that each of the ten study sites displayed a significantly different benthic fauna (pairwise tests, lowest $\mathrm{p}$-value $=0.038$ ). However, ordination of site centroids using PCO coupled to cluster analyses indicated affinities among the benthic fauna of the Aiguillon-Sèvre Niortaise, Gironde, Seine, Loire, Charente, Somme and Orne estuaries and separated the latter sites from the Belon, Bidassoa and Trieux estuaries (Fig. 2). At the distance of 50, the Belon estuary clustered alone whereas the Trieux and Bidassoa clustered together (Fig. 2). At a higher similarity level (i.e. lower distance of 45), the benthic fauna of the Orne and Somme systems were isolated from the main site group (Fig. 2a). None of the existing classifications tested (WFD, those of Nicolas et al (2010) and Galvan et al. (2010)) showed a good agreement with the fauna pattern (Fig. 2b,c and d). However, part of this lack of agreement may be due to some inconsistencies in the computation of hydromorphological indicators due to the way each estuary was spatially delimited. The BEST procedure highlighted the relations between the ordination of site centroids and some of the physical variables (Table 1). More precisely, the best correlation between environmental and fauna data $(\mathrm{Rho}=0.68, \mathrm{p}=0.02)$ was obtained when including River discharge:estuarine volume ratio $(\mathrm{R}: \mathrm{V})$, Closure Index (CI), slope and average suspended particulate matter levels (SPM). This result showed that the fauna of these estuarine systems differed according to the combination of the relative importance of freshwater inputs, the relative importance of the connection to the sea, the ratio between the main source elevation and the length of the main tributaries and the level of suspended particulate matter. However, it should be noticed that, in our dataset, these four variables were correlated with other morphological, hydrological and sedimentary variables (Table 2). For instance, SPM level was correlated to the absolute value of river discharge $\left(R, R_{s}=0.76\right)$, smaller intertidal area (int, $R_{s}=0.68$ ) and lower proportion of tidal prism regarding with estuarine volume (TP:V, $\left.\mathrm{R}_{\mathrm{s}}=-0.68\right)$.

\subsubsection{Species diversity}

Compared on the basis of ten samples $\left(2 \mathrm{~m}^{2}\right)$, the total number of taxa recorded in each estuary varied from 58 in the Bidassoa estuary to only 21 in the Loire estuary (Fig. 3). Sites displaying the highest $\gamma$ - 
diversity were the Bidassoa, Belon and Trieux estuaries with more than 40 taxa, whereas the lowest numbers of taxa $(<30)$ were recorded within the Gironde, Loire, Somme and Seine estuaries. The Aiguillon, Charente and Orne estuaries displayed intermediate (33 to 40 taxa) levels of $\gamma$-diversity (Fig. 3). Correlation between $\gamma$-diversity level and environmental variables studied at the site-scale showed that there were significant negative correlations between $\gamma$-diversity and both SPM concentrations $\left(R_{S}=-0.70, p<0.05\right)$ and total surface of intertidal area $\left(R_{S}=-0.86, p<0.05\right)$.

At the scale of one station, the mean $\alpha$-diversity was significantly different among sites (PERMANOVA , $\mathrm{p}<0.001$ ). Pairwise tests showed that there was a tendency of decreasing $\alpha$-diversity from the species-dense stations of the Bidassoa, Trieux and Belon estuaries toward the species-poor Seine, Gironde and Loire estuaries. Other sites displayed intermediate levels of species-density. The level of $\alpha$-diversity among sites was significantly positively correlated to both relative proportion of intertidal area and ratio between tidal prism volume and freshwater discharge volume $\left(R_{S}>0.78\right.$ and $p-$ values $<0.05$ ). A negative correlation was observed with both SPM concentration and total intertidal area $\left(\mathrm{R}_{\mathrm{S}}<-0.76\right.$ and $\mathrm{p}$-values $\left.<0.05\right)$.

In terms of $\beta$-diversity, Whittaker's $\beta \mathrm{w}$ values were significantly lower in the Bay of Somme compared to the Belon and Orne estuaries. The values of average $\beta \mathrm{w}$ were only positively correlated to the TP: $R$ ratio $\left(R_{S}=-0.63, p<0.05\right)$.

Relationship among the three components of diversity at the scale of sites showed that there was a general linear relation between the $\alpha$-component of diversity and $\gamma$-diversity indicating that variations in average $\alpha$-diversity explained more than $65 \%$ of the variations in $\gamma$-diversity among sites $\left(\mathrm{R}^{2}=0.65\right.$, $\mathrm{p}<0.05$ ) (Fig. 4). In addition, discrepancy from the general model indicated higher contribution of (relative) $\beta$-diversity to $\gamma$-diversity in the Belon, Trieux and Orne estuaries and low $\beta$-diversity in the Loire, Somme, Aiguillon-Sèvre Niortaise and Bidassoa estuarine systems (Fig. 4).

\subsubsection{Pattern in trophic organization}

Partitioning $\gamma$-diversity among trophic groups, there was first a significant linear relationship between the total number of species (estimated on $2 \mathrm{~m}^{2}$ ) and the number of taxa for every trophic group $(\mathrm{R}>0.79$, all $\mathrm{p}$-values $<0.05)$.

There was a negative relationship between the number of interface-feeding and subsurface depositfeeding taxa and SPM concentrations (both $R_{S}<-0.65$, both p-value <0.05, Fig. 5). As well, the number of suspension-feeding species displayed a sharp decrease in relation to increased SPM concentrations levels (Fig. 5). Subsurface-deposit feeders diversity was also negatively correlated to average sediment grain-size (in $\Phi$ unit), indicating that the diversity of these organisms was lower in mud than in sandy sediments $\left(R_{S}=-0.66\right)$. The number of species of grazers $(G)$ was low $(<4$ species $)$ and consequently did not displayed any particular pattern (Fig. 5). Carnivorous/omnivorous species number did not show any particular pattern among estuaries (Fig. 5).

\subsection{Within-sites patterns}




\subsubsection{Benthic macrofauna assemblages and associated environmental factors}

On the basis of fauna similarities among stations, SIMPROF procedure identified 33 homogeneous clusters among which only 22 included more than 2 stations (Fig. 6). At a similarity level of 10\%, 4 main (i.e. gathering more than 2 stations) station groups were observed (Fig. 6). The largest group (group III) gathered the largest number of stations within each site with the exception of the Belon and the Somme estuaries. This station group was mainly characterized by Hediste diversicolor, Nephtys hombergii, oligochaetes, Scrobicularia plana, Macoma balthica and Peringia ulvae (Table 3). Within this group, sediments ranged from pure mud to slightly muddy sands. These stations were either located throughout the Aiguillon, Orne and Somme estuaries or occupied most of the Gironde, Loire, Charente and Seine estuaries except the very lower (Gironde) or upper (Loire, Charente and Seine) parts of these systems (Fig. 6 and 7). Most stations within the Belon estuary gathered into group IV while only two upstream stations gathered in the largest group III (Fig. 6 and 7). Stations from group IV were located throughout the Belon estuary where sediments ranged from muddy coarse sediments to sandy muds with less than $40 \%$ fine particles (Fig. 6 and 7). These stations were mainly characterized by Nephtys hombergii and N. hystricis, cirratulids, Owenia fusiformis, Spio spp., oligochaetes and Angulus tenuis (Table 3). Within the Bay of Somme, half of the stations gathered in group III and the other half in a separate group (group II) (Fig. 7). This latter group gathered stations consisting in clean sands or coarse sediments with very little mud content $(<4 \%)$ located in the lower part of the Gironde estuary and upper parts of the Orne and Seine estuaries as well as throughout the Bay of Somme. This group was characterized by amphipods of the families Bathyporeiidae and Haustoriidae and Eurydice spp. (Table 3). Within the Orne estuary, four stations were isolated in group V which was restricted to the lower part of this system on the same kind of clean sand and coarse sediments than in the previous group (group II) (Fig. 6 and 7). This group was characterized by the presence of mussel beds (Mytilus edulis), Scolelepis squamata and Ophelia rathkei (Table 3). Station group I only gathered two stations from the Charente and Loire estuaries that were located on muds from the uppermost parts of these sites. In these stations the benthic fauna almost only consisted in Boccardiella sp. (Table 3).

At $20 \%$ similarity level, additional clusters were identified within group III. These clusters mainly isolated stations within the Bidassoa estuary (group G), the Gironde, Loire, Charente estuaries (group E), the Seine estuary (group F) and the Trieux estuary (group D) while most stations remained within the largest group H. Stations from the Trieux (D vs H) estuaries were separated according to both their position within the estuary and a different mud content which was lower in the lower part of this system (Table 4, Fig. 6 and 7). Within the Gironde, Loire, Bidassoa, Charente and Seine estuaries, the separation was correlated to the position of stations within the estuary $(\mathrm{G} v s \mathrm{H}$ in the Bidassoa estuary, E vs $\mathrm{H}$ in the other systems, Table 4) as well as the difference in mud content in the Seine estuary (F vs $\mathrm{H}$, Table 4). Within the Belon estuary, stations from group IV were split into two different groups (I 
vs J) correlated to slight differences in sediment types (Table 4). Species characterizing each group are indicated in Table 3.

At $30 \%$ similarity level, different clusters were identified within group H. However, only stations within the Charente, Loire, Orne and Gironde were separated at this level of similarity. In other sites, all stations remained in the same group. The separation of stations into different groups appeared to be correlated to their position within the Charente and Gironde estuaries (III-H12 vs III-H8) or to both mud content and position within the Loire (III-H11 vs III-H9) or mostly in relation to mud content within the Orne estuary (H12 vs H10 vs H9) (Table 4, Fig. 6 and 7).

According to DISTLM results, variations in sediment characteristics explained a larger part of the variation in benthic fauna than distance to ocean within the Aiguillon, Orne and Somme estuarine systems (Table 4). Sediments grain-size explained a similar part of variation than distance to ocean within the Belon, Trieux and Gironde estuaries; however, both factors were (negatively) correlated in the latter system (Table 4). Distance to ocean, which represented a proxy of salinity level, mathematically explained a large part of fauna variations within the Bidassoa, Charente, Loire, Seine estuaries (Table 4). In these systems, this factor explained at least more than $30 \%$ of fauna variations while grain-size only explained more than $20 \%$ of variations within the Seine, Trieux and Orne estuaries (Table 4). Finally, combination of both factors increased the explained fauna variations of more than $10 \%$ within the Gironde, Orne, Seine, Somme and Trieux estuaries (Table 4). As a conclusion, distance to ocean appeared as the only main explanatory variable within the Bidassoa, Charente and Loire estuaries. Variations in sediments appeared as the only main explanatory variable within the Aiguillon and Somme and both factors appeared as additive within the Gironde, Orne, Seine and Trieux estuaries. Within assemblage III, variations in fauna were only correlated to station position in the Bidassoa, Charente, Loire and Gironde and mainly associated with this factor, in addition to sediments, within the Orne, Seine and Trieux (Table 4). Within group H, station position in the salinity gradient also appeared as the main explanatory variable in the Gironde and Charente and in addition with sediments within the Loire and Orne estuaries (Table 4).

\subsubsection{Within-sites pattern of species diversity}

There were significant positive (rank-) correlations between $\alpha$-diversity (number of species per station) and proximity to ocean within the Bidassoa, Belon, Charente, Seine, Loire, Orne estuaries (Fig. 8). This pattern was also significant (Spearman $\mathrm{R}=0.71$ ) within the Gironde estuary when excluding the most downstream stations that corresponded to species-poor exposed mobile sands (Fig. 8). This pattern was significant neither within the Aiguillon-Sèvre Niortaise and Somme systems nor within the Trieux estuary (Fig. 8). In addition to this pattern, a lower level of $\alpha$-diversity was observed in both the clean sands assemblages (II-C, II-B and V-K) and in the upstream muddy assemblages III-E and IA compared to assemblages IV-I, IV-J, III-G (PERMANOVA and pairwise tests, p-values < 0.05 ). Assemblage III-H displayed an average level of diversity mainly as a function of its position within each estuary (Fig. 8). 


\section{Discussion}

\subsection{Classification of estuarine systems and relation with environmental factors}

When considered at the scale of the whole site, each of the estuarine system studied displayed a significantly different intertidal benthic fauna (PERMANOVA, factor 'site', $\mathrm{p}<0.05$ ) (Fig. 2). There was however a high similarity of fauna among estuarine systems characterized by high suspended particulate matter (SPM) concentrations associated to strong and less variable influence of freshwater discharge and low slope from source to sea. According to Fairbridge (1980)'s classification, these estuaries correspond to coastal plain estuaries which long tributaries mainly flow through low plains and carry fine sediments forming extensive mudflats (Day et al., 1989; Perillo, 1995). In our study these coastal plain estuaries included the Gironde, Charente, Aiguillon-Sèvre Niortaise, Loire and Seine estuarine systems. Conversely, estuarine systems characterized by low SPM, highly variable and generally lower influence of freshwater inputs and high slope, displayed a different benthic fauna. These estuaries can be considered as rias (Fairbridge, 1980; McLusky and Elliott, 2004) where the main tributary is short and mainly flows through granite substrates (Pyrenees mountains (Bidassoa) or Armorican massif (Belon and Trieux)) (Perillo, 1995). Within the coastal plain estuaries, there were however variations according to lower degree of isolation from the sea, lower relative freshwater influence and lower SPM concentrations in the case of the Somme estuarine system. In addition, high slope combined to moderate level of SPM as observed in the Orne estuarine system were correlated to variations within the coastal plain estuaries-type. None of the estuarine classifications used here, namely the transitional water bodies classification from the Water Framework Directive (WFD), the classification from Nicolas et al. (2010) or the classification proposed by Galván et al. (2010), was related to the observed pattern of benthic fauna among the estuaries studied here. Despite its suitability to reflect the main patterns of benthic fauna among estuary types, the classification of Galván et al. (2010) failed at correctly classifying the estuarine systems studied. The latter study was indeed based on estuaries from the Cantabrian coast only and our study only included intertidal macrofauna while this information was not given by Galván et al (2010). These estuaries, like those of the Basque country, are relatively small estuarine systems with small catchment areas and which sources are located at high altitudes in the nearby Cantabrian mountains (Valencia et al., 2004; Galván et al., 2010 and references therein); as a consequence estuaries of the coastal plain-type were not included in this classification. In accordance with the conclusions of Galván et al. (2010) we propose a modification of their classification system by including slope and SPM concentration in order to identify coastal plain estuaries.

Proposing precise threshold values would require additional comparisons including a larger set of estuaries at the European scale, which is beyond the scope of this study. Our results suggest that estuaries where SPM concentrations are higher than ca. $50 \mathrm{mg} . \mathrm{L}^{-1}$ should be considered for inclusion in the 'coastal plain estuary' type. Such a threshold-value is not only suggested by our empirical results; it was also suggested by different authors dealing with limiting factors for water column 
primary production in coastal areas and estuaries. Theoretically, this level of SPM would indeed correspond to a euphotic depth $\left(\mathrm{Z}_{\mathrm{eu}}\right)$ of less than $2 \mathrm{~m}$ (Cloern, 1987; Irigoien and Castel, 1997). In shallow estuaries, with a maximum depth $\left(\mathrm{Z}_{\mathrm{m}}\right)$ of ca. $10 \mathrm{~m}$ and assuming that water column is well mixed, this would correspond to a maximum $Z_{\mathrm{m}}: Z_{\mathrm{eu}}$ ratio of less than 5-6 above which no net phytoplankton production has been observed in estuaries (e.g. Cole and Cloern, 1984; Grobbelaar, 1985; Irigoien and Castel, 1997). Considering its consequence on estuary primary production and, thus, benthic organisms, this rough threshold-value should be taken into account for an estuarine classification. In addition to their consequence on primary production at the ecosystem-scale, high SPM concentrations have a detrimental effect on suspension-feeding organisms especially on bivalves which filtering and respiration apparatus is clogged by too high SPM levels despite the ability of bivalves to cope with increasing SPM level by increasing pseudofaeces production and/or filtration rate. In the long-term the energetic cost and consequences on the scope-for-growth and reproduction (and consequently the occurrence of a species) of these organisms might be too low at this level of SPM concentration (Dame, 1996 and references therein). This is suggested by our observation considering the sharp decrease in the number of suspension-feeding species as a function of increasing SPM concentration (Fig. 5). However, it is clear that this relation is only based on correlation and on a relatively small number of cases. Moreover, confounding factors might occur and complicate this relation, such as the effect of salinity on diversity and between-sites differences in the SPM composition (Abril et al., 2002) with possible consequence on its nutritional value for organisms (e.g. Bayne et al., 1993; Navarro et al., 1998). The influence of high SPM concentration and the associated physical characteristics has already been evidenced by Warwick et al. (1991) through the comparison of the intertidal benthic fauna of six estuaries from southern UK. The latter study evidenced the originality of the benthic fauna of the hypertidal and highly turbid Severn estuary compared to the other five estuaries. In the same way, Ysebaert et al. (1998) reported few differences in the benthic macrofauna between the Ems-Dollard and Westerschelde estuaries which are both characterized by moderate to high levels of SPM. In addition, Meire et al. (1991) evidenced strong differences of benthic fauna between the Westerschelde and Oosterschelde in relation to low SPM concentrations in the latter ecosystem as a consequence of human-induced modifications of hydrology.

High slopes characterized ria-type estuaries such as the Bidassoa, Trieux and Belon estuaries. However, considering a classification methodology, our results suggest that slope should be subordinate to SPM concentration. Indeed, the Gironde estuary displays a high slope (4.5\%) whereas its benthic fauna is typical of the coastal plain estuary type. This observation suggests the preponderant effect of SPM concentrations on benthic fauna. An absolute classification of these different transitional water bodies into strictly-defined rias is complicated by the fact that several classifications have been proposed according to which characteristics was considered (hydrodynamics, geology, sedimentology of geomorphology). As a consequence, agreement among these classifications is only partial. For instance, the Bidassoa estuary is considered as river valley flooded during post- 
glacial sea level rise in the last stages of the Pleistocene and early Holocene, and not considered as a ria stricto sensu on the basis of hydrodynamics and sedimentological characteristics (Castaing and Guilcher 1995). However, it is classified as ria according to geomorphological characteristics. Our results suggest non-negligible biological heterogeneity within these non-coastal plain estuaries.

There were strong differences in the relative influence of river discharge among the estuaries studied here. For instance, the Bidassoa estuary displayed the highest relative river discharge whereas both the Trieux and Belon ranked among the less river-influenced systems (Table 1). Curiously, the Bidassoa estuary displayed the highest level of number of species compared to all other estuaries studied. This observation is in complete contradiction with our expectation of lower diversity in more brackish estuaries. However, we used yearly-averaged values of river discharge. This estuary is characterized by the highest yearly variations of river discharge. In addition, this estuary is known to undergo very strong floods suggesting that low salinity conditions may only occur during a very restricted amount of time which is also a characteristic of the other estuaries of the Basque country (Valencia et al., 2004). During our low tide-sampling, water salinity along the channel indeed varied between 33 and 24 in the downstream sector and between 23 and 2, with a median value of 9, in the upstream sector. Hence, the salinity level was not particularly low in this estuary beside the flood periods. These observations suggest that the temporal pattern of river input should be included in establishing a typology. In addition, the Bidasoa estuary is an estuary very altered by antrophogenic activities, especially its morphology, and consequently its hydrodynamics, following land reclamation, reinforcement of dikes and deepening of channels for shipping, among others. These pressures have a potential capacity to modify benthic fauna composition of this estuary as well as some of the other estuaries considered here. Unfortunately determining change in the fauna of these estuaries due to human activities impacts was beyond the scope of this study: we hence first concentrated on trying to put in evidence which main physical characteristics best explained the main pattern of benthic fauna among and within these estuarine systems. Other impacts on fauna such as difference in chemical pollutions levels among estuaries should also be included when comparing the fauna of the different estuaries. Nevertheless assessing the overall level of pollution of an estuary represents a major challenge due to the broad diversity of pollutants occurring in estuaries, the huge differences in the concentration-impact relations among pollutants and the physico-chemical interactions modifying the chemical compounds (chemical speciation) that take place within estuaries. However first attempts of classifications have been performed they were not considered in this study (Delpech et al., 2010).

\subsection{Intertidal benthic assemblages in estuarine systems}

Although a benthos-constrained classification of estuarine systems would be helpful to compare transitional water bodies, for instance within the frame of the WFD, our results suggest that comparison among estuaries may be conducted at the smaller scale of intertidal benthic habitat (i.e. assemblages). 
Our study indeed showed that the intertidal areas of these estuaries shared one common assemblage that was spatially more or less well represented according to sites. This assemblage (assemblage III-H) occurred in all estuarine systems studied here. It displayed a typical set of taxa that have been reported in the literature as characterizing the "Macoma (balthica) community" (Petersen, 1913, 1918; Thorson, 1957) with variations in composition and diversity according to biogeographical patterns and environmental conditions. For instance, a "reduced" Macoma balthica community, where M. balthica was absent, was observed in the inner part of the Bidassoa estuary. This species indeed reaches its southern limit of distribution south of the Gironde estuary (Bachelet et al., 1980; Hummel et al., 2000) and is therefore absent from the Bidassoa estuary (Garmendia et al., 2003) as well as from the Spanish and Portuguese estuarine systems (Borja et al., 2004a). In our study sites, Scrobicularia plana and Cerastoderma edule were the most common bivalve species and occurred in all systems. This was consistent with the proposal of a Scrobicularia plana-Cerastoderma edule community by Borja et al. (2004a) for the southern part of NW Europe such as the Basque country which biogeographically includes the Bidassoa estuary. This community/assemblage was spatially well represented in all systems except in the less river-influenced system (Belon estuary) where SPM concentration was the lowest. As well, its spatial representation was lower in hypertidal systems where sands were well represented such as in the Bay of Somme, and Orne and Seine estuaries.

The assemblage III-H displayed different aspects ('facies') according to both salinity level and sediment types. More precisely, the most diverse aspect of this assemblage occurred in mud and muddy sands in the lowest part of coastal plain estuaries except when this area consisted in sand substrates such as in the Orne and Seine estuaries. Going upstream, associated to salinity level decrease, impoverished aspects of this assemblage occurred on all types of intertidal sediment (assemblages III-H 8, III-H 9 or III-H 11). These impoverished 'facies' were characterized by a reduced occurrence of molluscs. Further upstream, molluscs completely disappeared, as well as the occurrence of polychaetes and the assemblage was characterized by Corophium volutator and oligochaetes (assemblage III-E). In two estuarine systems where the stations were submitted to obvious human impact, such as the Loire (dredging in relation to the functioning of the Cordemais powerplant) and Charente (where these stations were located very close to one of the largest constructed wetland for water treatment in Europe; Modéran et al., 2010), the benthic assemblage consisted either almost only in Boccardiella sp. or stations were devoid of macrofauna (using a 1-mm mesh sieve). Within ria systems (Belon, Trieux and Bidassoa estuaries), the lower part of the estuary consisted in muddy sands or sands where species-rich assemblages occurred. These species-rich assemblages were either characterized by a mixture of a venerid bivalves-rich community ("Venus community", Thorson 1957) (assemblage II-G) with species from the 'Scrobicularia plana Cerastoderma edule community' or by a 'Tellina tenuis community' (Borja et al., 2004a) (assemblages I and $\mathrm{J}$ from the Belon estuary) or a mixture between the latter community and the ' $S$. plana-C. edule community' (assemblages III-D and IV-J from the Trieux estuary). When going 
upstream, another 'facies' of the 'S. plana - C. edule community' occurred (assemblage III-H 10), which was also characterized by a reduced occurrence of molluscs. The observed pattern of macrofauna are in accordance with previous investigations on the pattern of intertidal benthic fauna in the Loire (Marchand, 1993), Gironde (Bachelet et al., 1980), Bidassoa (Garmendia et al., 2003), Seine (Ducrotoy and Dauvin, 2008) and Somme (Ducrotoy et al., 1987) systems. In addition, all intertidal macrobenthic assemblages described here match those previously described within the existing classifications of marine habitats (Dauvin et al., 2008 and references therein) and more particularly with the one proposed in Britain and Ireland by Connor et al. (2004) which has been extended to the European scale and included in the EUNIS classification managed by the European Union Environment Agency (http://eunis.eea.europa.eu/). The occurrence and relatively large extent of the venerid/Tellina tenuis assemblage in the lower part of estuaries seems to be a distinguishing feature of ria-like estuaries. Such a pattern was indeed described for rias of the Basque country (Borja et al., 2004a, 2006; Junoy and Viéitez, 1990) and Galicia (e.g. Ria de Aldan; Lourido et al., 2010) but was not reported in other coastal plain estuaries such as the Westerschelde (Ysebaert et al., 2003) or the Oosterschelde (Meire et al., 1991). In their comparative study of southern England intertidal estuarine systems, Warwick et al. (1991) reported the presence of Tellina tenuis only in the lower part of the Exe estuary. Compared to the other estuaries from this latter study, this estuary is characterized by the shortest river ( $8.4 \mathrm{~km}$ length) combined to the high source elevation $(440 \mathrm{~m})$ resulting in the highest slope $(5.2 \%)$ among the studied systems. This community might be absent or highly reduced in coastal plain-type estuaries as a consequence of both low salinity and high SPM concentrations and associated inputs of fine particles in these systems, which may represent adverse conditions for these suspension-feeders-rich assemblages and result in sediments consisting in mud. In contrast, considering only the meso- to polyhaline part of estuaries, it appears that coastal plain estuaries with moderate to high SPM concentrations usually display mostly two main benthic intertidal communities: the 'S. plana/M. balthica-C. edule community' located on most part of the estuary and a mobile sand community characterized by Bathyporeia spp. and haustorid amphipods ('Pontocrates arenarius Eurydice pulchra community' of Borja et al., 2004a) restricted to sandy beaches or banks that are exposed to wave action and/or tidal currents. This was observed in the Somme, Gironde, Orne and Seine estuarine systems but not in the Charente nor Aiguillon-Sèvre Niortaise systems because the mouth of both systems is sheltered from wave action by islands, Oléron and Ré respectively. A similar pattern has been described in the Westerschelde and Ems estuaries (Ysebaert et al., 1998).

Assessment of the relative importance of position within the salinity gradient or sediments type in structuring the benthic assemblages within these estuaries is complicated by the correlation between these two parameters in some estuary. It was for instance the case within the Gironde, the Bidassoa, or the Belon where both grain-size and position within the estuarine gradient showed some level of covariation. Both variables, however, mathematically explained the fauna pattern in many cases but the position within the longitudinal gradient usually explained a larger part of the fauna pattern $(>30 \%$ 
and up to 56\%) in five cases whereas sediments only never explained more than $25 \%$ of variations. This suggest that, beyond a given point, the environmental constraint represented by decreasing salinity may be more determinant than sediment types for the benthic fauna, leading to a relatively homogeneous macrofauna among estuaries in these conditions. In these conditions only the specviespoor 'S. plana/M. balthica-C. edule community' occurred (Fig. 7 and 8). Our results however suggest that this may vary from estuaries to estuaries and that this ' $S$. plana/M. balthica-C. edule community' is further modified especially in terms of species diversity, when salinity level decreases (Figs. 7 and $8)$.

\subsection{Relation with benthic fauna diversity}

The levels of $\gamma$-diversity reported in this study are in the range of values reported in other estuarine systems or habitats in Northern Europe estuaries. The number of taxa scaled to the sampled area showed that the number of species was low. Compared to other estuarine intertidal areas, our estimates of $\gamma$-diversity of benthic fauna showed that the $\gamma$-diversity of coastal plain estuaries was usually very low, with good agreement between our data on the Loire, Gironde, Seine, Somme and Aiguillon and those from other coastal plain estuaries such as the Westerschelde or the Severn estuaries (Fig. 3). On the other hand, the rias displayed higher $\gamma$-diversity levels than coastal plain estuaries with similar patterns observed in the habitats of the Ría de Foz (Junoy and Viéitez, 1990), estuaries from the Basque country such as Gernika and Plentzia estuaries (García-Arberas and Rallo, 2002) or the Exe estuary in UK (Warwick et al., 1991). However, some estuaries did not show the expected pattern; for instance it was not the case for the basque estuary of La Arena which displayed one of the lowest levels of $\gamma$-diversity (García-Arberas and Rallo, 2002). In addition, the Humber estuary displayed a rather high $\gamma$-diversity (Fujii, 2007) but was classified as a typical coastal-plain estuary by McLusky and Elliott (2004). Unraveling the underlying environmental factors responsible for these discrepancies would require a more precise study of both the fauna and hydromorphology of all these systems. Finally, the impact of human modification of the hydromorphology as well as pollution would have to be taken into account to explain the full pattern.

At the scale of our study, the observed pattern of $\gamma$-diversity of intertidal macrofauna was mainly explained by difference in $\alpha$-diversity among estuaries. The sites which were dominated by speciespoor assemblages displayed the lowest $\gamma$-diversity. This was exemplified by the Loire estuary which benthic fauna only consisted in different facies of the "S. plana-C. edule community" associated to high SPM concentration and strong freshwater influence. A slightly higher level of $\gamma$-diversity was reached in the Somme, Gironde and Seine estuarine systems which displayed only two species-poor assemblages related to the 'S. plana-C. edule community' and the mobile sand assemblage. The Aiguillon-Sèvre Niortaise and Charente systems displayed higher level of diversity in association to stronger relative influence of the tidal prism and/or lower influence of river discharge but only displayed assemblages related to the 'S. plana-C. edule community'. The Orne estuary reached higher 
$\gamma$-diversity in association to the diversity of benthic assemblages occurring in the intertidal area of this system, in accordance to higher level of $\beta$-diversity. Finally, the ria systems displayed the highest level of diversity due to the presence and spatial extent of species-rich communities such as the venerid and the "T. tenuis" communities in association with the "S. plana-C. edule community". The occurrence of these communities probably results from the combination of low inputs of fine particles, low SPM concentrations and lower influence of river discharge. As a consequence, a pattern of decreasing $\gamma$ diversity with increased total surface of intertidal areas is observed. This pattern is challenging since the relation between number of species and area is one of the fundamental patterns observed in macroecology (Gaston and Blackburn, 2000). Moreover, compared to the patterns of fish diversity reported by Nicolas et al. (2010) where it was showed that the number of fish species recorded in estuaries given a comparable sampling effort actually increases with the size of the estuary, this was obviously not the case for intertidal benthic invertebrates in our study. Our observations however should be considered as preliminary since the investigated area is still very limited (for instance, Ysebaert and Herman (2002) reported 106 species in the Westerschelde when including a huge sampling effort $\left(>30 \mathrm{~m}^{2}\right)$ including both spatial (20 samples $\times 30$ stations) and temporal a (16-year survey) dimensions). Despite a probably insufficient sampling effort, the almost asymptotic shape of the species-accumulation curves however strongly suggest that the recorded number of intertidal macrobenthic species in the Seine, Loire, Gironde, Somme and Aiguillon-Sèvre Niortaise is extremely limited and much lower than in other systems. The relevance of this observed pattern might be put in question since it only concerns small intertidal macrofauna from soft sediments and does not include subtidal areas nor oligohaline and tidal freshwater zones. Possible explanations might include the historical heavy impact of human activities on estuarine systems or the homogeneity of benthic fauna in the largest intertidal areas which are dominated, in our study, by typical estuarine benthic fauna which very low diversity is one of the main feature in accordance to Elliott and Quintino (2007)'s 'estuarine paradox'. 


\section{Conclusions}

This study, based on the comparison of the main features of ten estuarine systems and their associated intertidal macrofauna assemblages, showed consistent patterns in the organization of intertidal benthic macrofauna in permanently open estuaries. As discussed in the literature, the low levels of both alpha and gamma diversity, the occurring intertidal benthic communities and spatial patterns in both assemblage succession and $\alpha$-diversity along the estuarine ecotone are classical for these types of estuaries (Attrill and Rundle, 2002; Elliott and Quintino, 2007; Whitfield et al., 2012). In the frame of the WFD our results suggest that estuarine water bodies might be compared providing that the comparison is operated at the level of similar habitats within estuaries. More particularly, our results showed that such a comparison should be based by comparing among intertidal habitats where the " $S$. plana - C. edule community" occurs. In this context we suggest that the definition of these comparable habitats should be based on the existing EUNIS classification (Connor et al., 2004). Such an approach implies to define reference conditions at the scale of each habitat at the very least to the level- 4 of this classification (see Connor et al., 2004).

\section{Acknowledgements}

This study was funded by the French National Agency for Waters and Aquatic Environments (ONEMA: Office National des Eaux et des Milieux Aquatiques) and piloted by IFREMER. Authors would like to thank H. Bouillard and P. Lebleu for their valuable help during field sampling and samples processing. We would like to thank F. Barros, S. Kim and K. Hammerstrom for their advices and stimulating discussions on estuaries and diversity. Authors also wish to thanks to anonymous reviewers for their valuable help in improving the original manuscript. 


\section{References}

Abril, G., Nogueira, M., Etcheber, H., Cabeçadas, G., Lemaire, E., Brogueira, M.J., 2002. Behaviour of organic carbon in nine contrasting European estuaries. Estuarine, Coastal and Shelf Science 54, 241262.

Anderson, M.J., Gorley, R.N., Clarke, K.R., 2008. PERMANOVA+ for PRIMER: Guide to Software and Statistical Methods. Plymouth, UK: PRIMER-E.

Anderson, M.J., Crist, T.O., Chase, J.M., Vellend, M., Inouye, B.D., Freestone, A.L., Sanders, N.J., Cornell, H.V., Comita, L.S., Davies, K.F., Harrison, S.P., Kraft, N.J.B., Stegen, J.C., Swenson, N.G.,. 2011. Navigating the multiple meanings of $\beta$ diversity: a roadmap for the practicing ecologist. Ecology Letters 14, 19-28.

Attrill, M.J., 2002. A testable linear model for diversity trends in estuaries. Journal of Animal Ecology 71, 262-269.

Attrill, M.J., Rundle, S.D., 2002. Ecotone or ecocline: ecological boundaries in estuaries. Estuarine, Coastal and Shelf Science 55, 929-936.

Bachelet, G., Bouchet, J.M., Lissalde, J.P., 1980. Les peuplements benthiques dans l'estuaire de la Gironde : biomasse, productivité et évolution structurale. Océanis 6, 593-620.

Bachelet, G., 1981. Données préliminaires sur l'organisation trophique d'un peuplement benthique marin. Vie et Milieu 31, 205-213.

Bald, J., Borja, A., Muxika, I., Franco, J., Valencia, V., 2005. Assessing reference conditions and physico-chemical status according to the European Water Framework Directive: a case-study from the Basque Country (Northern Spain). Marine Pollution Bulletin 50, 1508-1522.

Barbone, E., Rosati, I., Reizopoulou, S., Basset, A., 2012. Linking classification boundaries to sources of natural variability in transitional waters: A case study of benthic macroinvertebrates. Ecological Indicators 12, 105-122.

Barnes, R.S.K., 1989. What, if anything, is a brackish-water fauna? Transactions of the Royal Society of Edinburgh: Earth Sciences 80, 235-240.

Bayne, B L., Iglesias, J.I.P., Hawkins, A.J.S., Navarro, E., Héral, M., Deslous-Paoli, J.M., 1993. Feeding behaviour of the mussel, Mytilus edulis: responses to variations in quantity and organic content of the seston. Journal of the Marine Biological Association of the United Kingdom 73, 813-829.

Blanchet, H., Bachelet, G., de Montaudouin, X., Lavesque, N., Grémare, A., 2012. Biodiversity and bioevaluation methods in transitional waters: a theoretical challenge. Transitional Waters Bulletin 6, 1319.

Borja, A., Aguirrezabalaga, F., Martinez, J., Sola, J.C., Garcia-Arberas, L., Gorostiaga, J.M., 2004a. Benthic communities, biogeography and resources management. In: Borja, A., Collins, M. (Eds.), Oceanography and Marine Environment of the Basque Country. Elsevier, Amsterdam, pp. 455-492. 
Borja, Á., Franco, J., Valencia, V., Bald, J., Muxika, I., Belzunce, M.J., Solaun, O., 2004b. Implementation of the European water framework directive from the Basque country (northern Spain): a methodological approach. Marine Pollution Bulletin 48, 209-218.

Borja, Á., Muxika, I., Franco, J., 2006. Long-term recovery of soft-bottom benthos following urban and industrial sewage treatment in the Nervión estuary (southern Bay of Biscay). Marine Ecology Progress Series 313, 43-55.

Castaing, P., Guilcher, A., 1995. Chapter 4. Geomorphology and Sedimentology of Rias. In: G.M.E. Perillo (Editor), Geomorphology and Sedimentology in Estuaries. Developments in Sedimentology, 53. Elsevier Science B. V., Amsterdam, The Netherlands, pp. 69-107.

Clarke, K.R., Gorley, R.N., 2006. PRIMER v6: User Manual / Tutorial. Plymouth, UK: PRIMER-E.

Cloern, J.E., 1987. Turbidity as a control on phytoplankton biomass and productivity in estuaries. Continental Shelf Research 7, 1367-1381.

Cole, B.E., Cloern, J.E., 1984. Significance of biomass and light availability to phytoplankton productivity in San Francisco Bay. Marine Ecology Progress Series 17, 15-24.

Connor, D.W., Allen, J.H., Golding, N., Howell, K.L., Liederknecht, L.M., Northen, K.O., Reker, J.B., 2004. The marine habitat classification for Britain and Ireland. Version 04.05.

Dame, R.F., 1996. Ecology of marine bivalves: An Ecosystem Approach. CRC Press, Boca Raton.

Dauvin, J.C., 1993. Le benthos : témoin des variations de l'environnement. Océanis 19, 25-53.

Dauvin, J.-C., Bellan, G., Bellan-Santini, D., 2008. The need for clear and comparable terminology in benthic ecology. Part I. Ecological concepts. Aquatic Conservation: Marine and Freshwater Ecosystems 18:432-445.

Day, J.W., Hall, C.A.S., Kemp, W.M., Yanez-Arancibia, A., 1989. Estuarine ecology. John Wiley \& Sons, New York.

Delpech, C., Courrat, A., Pasquaud, S., Lobry, J., Le Pape, O., Nicolas, D.,Boët, P.,Girardin, M., Lepage, M., 2010. Development of a fish-based index to assess the ecological quality of transitional waters: The case of French estuaries. Marine Pollution Bulletin 60, 908-918.

de Paz, L., Patrício, J., Marques, J.C., Borja, A., Laborda, A.J., 2008. Ecological status assessment in the lower Eo estuary (Spain). The challenge of habitat heterogeneity integration: A benthic perspective. Marine Pollution Bulletin 56, 1275-1283.

Ducrotoy, J.P., Dauvin, J.C., 2008. Estuarine conservation and restoration: the Somme and the Seine case studies (English Channel, France). Marine Pollution Bulletin 57, 208-218.

Ducrotoy, J.P., 2010. The use of biotopes in assessing the environmental quality of tidal estuaries in Europe. Estuarine, Coastal and Shelf Science 86, 317-321.

Ducrotoy, J.P., Desprez, M., Elkaim, B., 1987. Crise de la production des coques (Cerastoderma edule) en Baie de Somme. II. Impact de la dynamique biosédimentaire. Revue des Travaux de l'Institut des Pêches Maritimes 49, 231-241. 
Elliott, M., Quintino, V., 2007. The estuarine quality paradox, environmental homeostasis and the difficulty of detecting anthropogenic stress in naturally stressed areas. Marine Pollution Bulletin 54, 640-645.

Elliott, M, Whitfield, A.K., 2011. Challenging paradigms in estuarine ecology and management. Estuarine, Coastal and Shelf Science 94, 306-314.

Fairbridge, R., 1980. The estuary: its definition and geodynamic cycle. In: Olausson, E. and Cato, I. (Eds.), Chemistry and Geochemistry of Estuaries. John Wiley and Sons, New York, pp. 1-35.

Farrel, K.M., Burleigh Harris, W., Mallinson, D. J., Culver, S. J., Riggs, S.R., Pierson, J., Self-Trail J.M., Lautier, J.C., 2012. Standardizing texture and facies codes for a process-based classification of clastic sediment and rock. J. sediment. Res. 82, 364-378.

Fauchald, K., Jumars, P.A., 1979. The diet of worms: a study of polychaete feeding guilds. Oceanography and Marine Biology an Annual Review 17, 193-284.

Fujii, T., 2007. Spatial patterns of benthic macrofauna in relation to environmental variables in an intertidal habitat in the Humber estuary, UK: Developing a tool for estuarine shoreline management. Estuarine, Coastal and Shelf Science 75, 101-119.

Galván, C., Juanes, J.A., Puente, A., 2010. Ecological classification of European transitional waters in the North-East Atlantic eco-region. Estuarine, Coastal and Shelf Science 87, 442-450.

García-Arberas, L., Rallo, A., 2002. The intertidal soft-bottom infaunal macrobenthos in three Basque estuaries (Gulf of Biscay): a feeding guild approach. Hydrobiologia 475/476, 457-468.

Garmendia, L., Marquiegui, M., Aguirrezabalaga, F., Cruz, I., Cantón, L., 2003. Efecto de la desaparición de los vertidos de aguas residuales urbanas sobre la comunidad reducida de Macoma en las islas del estuario del río Bidasoa (golfo de Vizcaya). Boletín Instituto Español de Oceanografía 19, 265-281.

Gaston, K.J., Blackburn, T.M., 2000. Pattern and process in macroecology. Blackwell Science, Oxford.

Gray, J.S., 2000. The measurement of marine species diversity, with an application to the benthic fauna of the Norwegian continental shelf. Journal of Experimental Marine Biology and Ecology 250, 23-49.

Grobbelaar, J.U., 1985. Phytoplankton productivity in turbid waters. Journal of Plankton Research 7, 653-663.

Hily, C., Bouteille, M., 1999. Modifications of the specific diversity and feeding guilds in an intertidal sediment colonized by an eelgrass meadow (Zostera marina) (Brittany, France). Comptes Rendus de l'Académie des Sciences de Paris, Series III, Sciences de la Vie 322, 1121-1131.

Hume, T.M., Snelder, T., Weatherhead, M., Liefting, R., 2007. A controlling factor approach to estuary classification. Ocean \& Coastal Management 50, 905-929.

Hummel, H., Bogaards, R.H., Bachelet, G., Caron, F., Sola, J.C., Amiard-Triquet, C., 2000. The respiratory performance and survival of the bivalve Macoma balthica (L.) at the southern limit of its distribution area: a translocation experiment. Journal of Experimental Marine Biology and Ecology 251, 85-102. 
Irigoien, X., Castel, J., 1997. Light limitation and distribution of chlorophyll pigments in a highly turbid estuary: the Gironde (SW France). Estuarine, Coastal and Shelf Science 44, 507-517.

Junoy, J., Viéitez, J.M., 1990. Macrozoobenthic community structure in the Ría de Foz, an intertidal estuary (Galicia, Northwest Spain). Marine Biology 107, 329-339.

Le Bris, H., 1988. Fonctionnement des écosystèmes benthiques côtiers au contact d'estuaires : la rade de Lorient et la baie de Vilaine. PhD thesis, Université de Bretagne Occidentale. 311 pages.

Little, C., 2000. The biology of soft shores and estuaries. Oxford University Press, New York.

Lourido, A., Moreira, J., Troncoso, J.S., 2010. Spatial distribution of benthic macrofauna in subtidal sediments of the Ría de Aldán (Galicia, northwest Spain). Scientia Marina 74, 705-715.

Maguran, A.E., 2004. Measuring biological diversity. Blackwell, Oxford.

Marchand, J., 1993. The influence of seasonal salinity and turbidity maximum variations on the nursery function of the Loire estuary (France). Aquatic Ecology 27, 427-436.

McLusky, D., Elliott, M., 2004. The Estuarine Ecosystem. Ecology, threats, and managements. Third Edition. Oxford University Press, New York.

Meire, P.M., Seys, J.J., Ysebaert, T.J., Coosen, J., 1991. A comparison of the macrobenthic distribution and community structture between two estuaries in SW Netherlands. In: Elliott, M., Ducrotoy, J.P. (Eds), Estuaries and Coasts: Spatial and Temporal Intercomparisons. Olsen \& Olsen, Fredensborg, Denmark, pp. 221-230.

Modéran, J., Bouvais, P., David, V., Le Noc, S., Simon-Bouhet, B., Niquil, N., Miramand, P., Fichet, D., 2010. Zooplankton community structure in a highly turbid environment (Charente estuary, France): spatio-temporal patterns and environmental control. Estuarine, Coastal and Shelf Science 88, 219-232.

Navarro, E., Urrutia, M.B., Iglesias, J.I.P., Ibarrola, I., 1998. Tidal variations in feeding, absorption and scope for growth of cockles (Cerastoderma edule) in the bay of Marennes-Oléron (France). Vie et Milieu 48, 331-340.

Nicolas, D., Lobry, J., Lepage, M., Sautour, B., Le Pape, O., Cabral, H., Uriarte, A., Boët, P., 2010. Fish under influence: a macroecological analysis of relations between fish species richness and environmental gradients among European tidal estuaries. Estuarine, Coastal and Shelf Science 86, 137-147.

Nunes, M., Coelho, J.P., Cardoso, P.G., Pereira, M.E., Duarte, A.C., Pardal, M.A., 2008. The macrobenthic community along a mercury contamination in a temperate estuarine system (Ria de Aveiro, Portugal). Science of The Total Environment 405, 186-194.

Perillo, G.M.E., 1995. Definitions and geomorphological classifications of estuaries. In: Perillo, G.M.E. (Ed.), Geomorphology and Sedimentology of Estuaries. Elsevier, pp. 17-47.

Petersen, C.G.J., 1913. Valuation of the sea II. The animal communities of the sea-bottom and their importance for marine zoogeography. Report of the Danish Biological Station 21, $44+68$ p. 
Petersen CGJ (1918) The sea-bottom and its production of fish food. Reports of the Danish Biology Station 25:1-62

Remane, A., 1934. Die Brackwasserfauna. Verhandlung der deutschen zoologischen Gesellschaft 36, 34-74.

Remane, A., Schlieper, C., 1958. Die Biologie des Brackwassers. Stuttgart: Schweizerbart'sch Verlagsbuchhandlung.

Rodrigues, A.M., Meireles, S., Pereira, T., Quintino, V., 2006. Spatial patterns of benthic macroinvertebrates in intertidal areas of a Southern European estuary: the Tagus, Portugal. Hydrobiologia 555:99-113.

Rodrigues, A.M., Quintino, V., Sampaio, L., Freitas, R., Neves, R., 2011. Benthic biodiversity patterns in Ria de Aveiro, Western Portugal: Environmental-biological relationships. Estuarine, Coastal and Shelf Science 95, 338-348.

Sauriau, P.G., Mouret, V., Rincé, J.P., 1989. Organisation trophique de la malacofaune benthique non cultivée du bassin ostréicole de Marennes-Oléron. Oceanologica Acta 12, 193-204.

Siegel, S., 1956. Nonparametric statistics for the behavioral sciences. McGraw-Hill.

Tenore, K.R., Zajac, R.N., Terwin, J., Andrade, F., Blanton, J., Boynton, W., Carey, D., Diaz, R., Holland, A.F., López-Jamar, E., Montagna, P., Nichols, F., Rosenberg, R., Queiroga, H., Sprung, M., Whitlatch, R.B., 2006. Characterizing the role benthos plays in large coastal seas and estuaries: a modular approach. Journal of Experimental Marine Biology and Ecology 330, 392-402.

Thorson, G., 1957. Bottom communities (sublittoral or shallow shelf). Geological Society of America Memoir 67, 461-534.

Valencia, V., Franco, J., Borja, A., Fontan, A., 2004. Hydrography of the southeastern Bay of Biscay. In: Borja, A., Collins, M. (Eds.), Oceanography and Marine Environment of the Basque Country. Elsevier, Amsterdam, pp. 159-194.

Warwick, R.M., Goss-Custard, J.D., Kirby, R., George, C.L., Pope, N.D., Rowden, A.A., 1991. Static and dynamic environmental factors determining the community structure of estuarine macrobenthos in SW Britain: why is the Severn Estuary different? Journal of Applied Ecology 28, 329-345.

Whitfield, A.K., Elliott, M., Basset, A., Blaber, S.J.M., West, R.J., 2012. Paradigms in estuarine ecology - A review of the Remane diagram with a suggested revised model for estuaries. Estuarine, Coastal and Shelf Science 97, 78-90.

Ysebaert, T., Meire, P., Maes, D., Buijs, J., 1993. The benthic macrofauna along the estuarine gradient of the Schelde estuary. Netherlands Journal of Aquatic Ecology 27, 327-341.

Ysebaert, T., Meire, P., Coosen, J., Essink, K., 1998. Zonation of intertidal macrobenthos in the estuaries of Schelde and Ems. Aquatic Ecology 32, 53-71.

Ysebaert, T., Herman, P.M.J., 2002. Spatial and temporal variation in benthic macrofauna and relationships with environmental variables in an estuarine, intertidal soft-sediment environment. Marine Ecology Progress Series 244, 105-124. 
Ysebaert, T., Herman, P.M.J., Meire, P., Craeymeersch, J., Verbeek, H., Heip, C.H.R. 2003. Largescale spatial patterns in estuaries: estuarine macrobenthic communities in the Schelde estuary, NW Europe. Estuarine, Coastal and Shelf Science 57:335-355. 


\section{Figures captions}

Fig. 1: Location of the ten study sites along the French coast.

Fig. 2: (a.) Principal coordinates ordinations of site centroids according to their fauna composition. Contours indicate site centroids gathering together at distances of 50 (full black line) and 45 (grey dotted line) according to cluster analysis (obtained by group average method). Correlation with physical variables (\% int: classes of relative intertidal area, R:V: ratio between the estimated volume of river inputs during a tidal cycle $(12 \mathrm{H})$ and estimated estuarine water volume at average high tide, $\mathrm{CI}$ : closure index (Hume et al., 2007), SED: median value of average sediment grain-size, vSED: coefficient of variation of average sediment grain size, slope: average slope of the river-estuary system, SPM: level of suspended particulate matter concentrations in water, see Table 1 for full details) are represented. Comparisons with existing classification in the scope of the WFD are provided including (b.) fish-based classification developed by Nicolas et al. (2010) (classification mainly related to estuarine-size with estuaries classified from the largest (A) to smallest $(\mathrm{G})$ ); (c.) WFD classification of water bodies including T01: polyhaline small estuary with large intertidal area and average turbidity level, T03: small estuary with small intertidal area and low turbidity level, T05: small to medium-size macrotidal estuary with high salinity and average river discharge level, T07: large estuary with mean to high salinity level and high level of river discharge, T08: small estuary with small intertidal area and high to medium turbidity level, T09: small estuary with large intertidal area, low turbidity and high level of salinity; (d.) benthos-based classification of transitional water bodies proposed by Galván et al. (2010) (ITE: Intertidal Tidal Elongated water body, ITR: Intertidal Tidal Rounded water body).

Fig. 3: Species-accumulation curves drawn for each study site (grey lines) showing the number of taxa accumulating over a cumulated sampled area (in $\mathrm{m}^{2}$ ). These curves are compared to available data of $\gamma$-diversity from other intertidal estuarine and coastal areas along the European North Sea - Atlantic coasts (HUM: Humber (Fujii, 2007); GER: Gernika, LAR: La Arena, PLE: Plentzia (García-Arberas and Rallo, 2002); SCV: Scorff and Blavet estuaries (Le Bris, 1988); OOS: Oosterschelde, WES1: Westerschelde (Meire et al., 1991); AVE: ria de Aveiro (Nunes et al., 2008); EXE: Exe, PLY: Plym, POO: Poole Harbour, SEV: Severn, SHO: Southampton Water, TAM: Tamar (Warwick et al., 1991); WES2: Westerschelde (Ysebaert et al., 1993); WES3: Westerschelde (Ysebaert et al., 2003); TAG1-6: Tagus (Rodrigues et al., 2006).

Fig. 4: Relation between the $\alpha$ - and $\gamma$ - components of diversity at the site-scale estimated by the average number of taxa per station $\left(0.2 \mathrm{~m}^{2}\right)$ and estimated total number of taxa on $2 \mathrm{~m}^{2}$ (through permutation and species-accumulation), respectively. The linear relation between both variables was 
obtained by linear regression and is indicated together with the $\mathrm{R}^{2}$ value. Discrepancy between observed levels of $\gamma$-diversity and $\alpha$-diversity from the model implies $\beta$-diversity effect. Site-points located under the curve indicate relative lower-than-average level of $\beta$-diversity whereas site-points located above the curve indicate relative higher-than-average level of $\beta$-diversity according to a model of multiplicative effect of $\beta$-diversity where $\gamma=\beta \times \alpha$.

Fig. 5: Relation between estimated $\gamma$-diversity (estimated number of taxa over $2 \mathrm{~m}^{2}$ ) of each trophic group and suspended particulate matter concentration levels (see Table 1 for the correspondence of SPM-level). IF: interface feeders, SSDF: subsurface deposit-feeders, C-O: carnivores and omnivores, SF: suspension feeders, G: grazers.

Fig. 6: Dendrogram issued from the hierarchical classification of stations from all estuaries. Below the dendrogram, the number of stations belonging to each group identified on the basis of the dendrogram structure and SIMPROF procedure is indicated together with (a) sediment type and (b) position (\% downstream) within the estuarine gradient. This is indicated for each level of the classification (i.e. at 10, 20 and 30\% similarity levels). For clarity, only station groups identified at the $10 \%$ level are indicated on the figure. Similarity (\%) corresponds to Bray-Curtis similarity coefficient. Sediment types are indicated by: CS: coarse sediments, S: sands, mS: muddy sands, sM: sandy muds and M: muds (based on the classification proposed by Farrel et al. (2012)). Values indicated in subtable (a) are the number of stations per sediment types. Values indicated in subtable (b) is the average position (in $\%$ downstream) of these stations for each sediment types.

Fig. 7 Schematic representation of the succession of benthic assemblages within the studied estuaries as a function of sediment type on the vertical axis (CS: coarse sediments, S: sands, mS: muddy sands, sM: sandy muds and M: muds (based on the classification proposed by Farrel et al. (2012))) and position in the estuarine salinity gradient (horizontal axis, not at scale). See Fig. 6 for benthic assemblages codes.

Fig. 8: Relations between number of taxa per station ( $\alpha$-diversity, $S$ ) and position of station within the estuarine gradient (proximity to ocean $(\%)$ ). $R_{S}$ is the Spearman rank-correlation coefficient between number of taxa and relative proximity to downstream boundary of the estuarine system (\%).The level of statistical signification of $\mathrm{R}_{\mathrm{s}}$ is given $\left({ }^{n s}\right.$ : non significant $(\mathrm{p}>0.05)$, *: significant $\left.(\mathrm{p}<0.05)\right)$. Two $\mathrm{R}_{\mathrm{s}}$ values were computed in the case of the Gironde estuary either including all stations or excluding the two most downstream stations which correspond to exposed sandy beaches. 


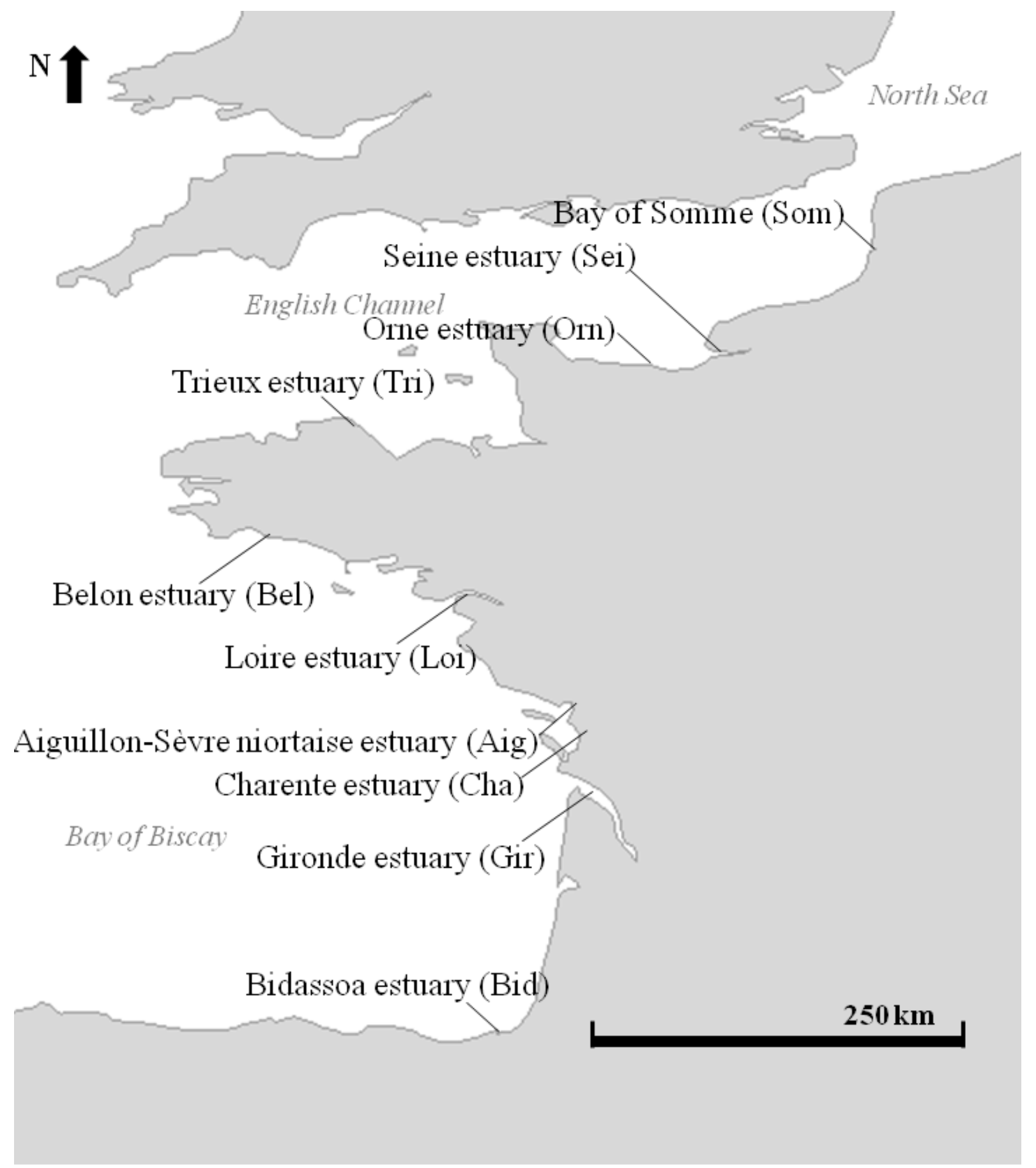

Fig 1 

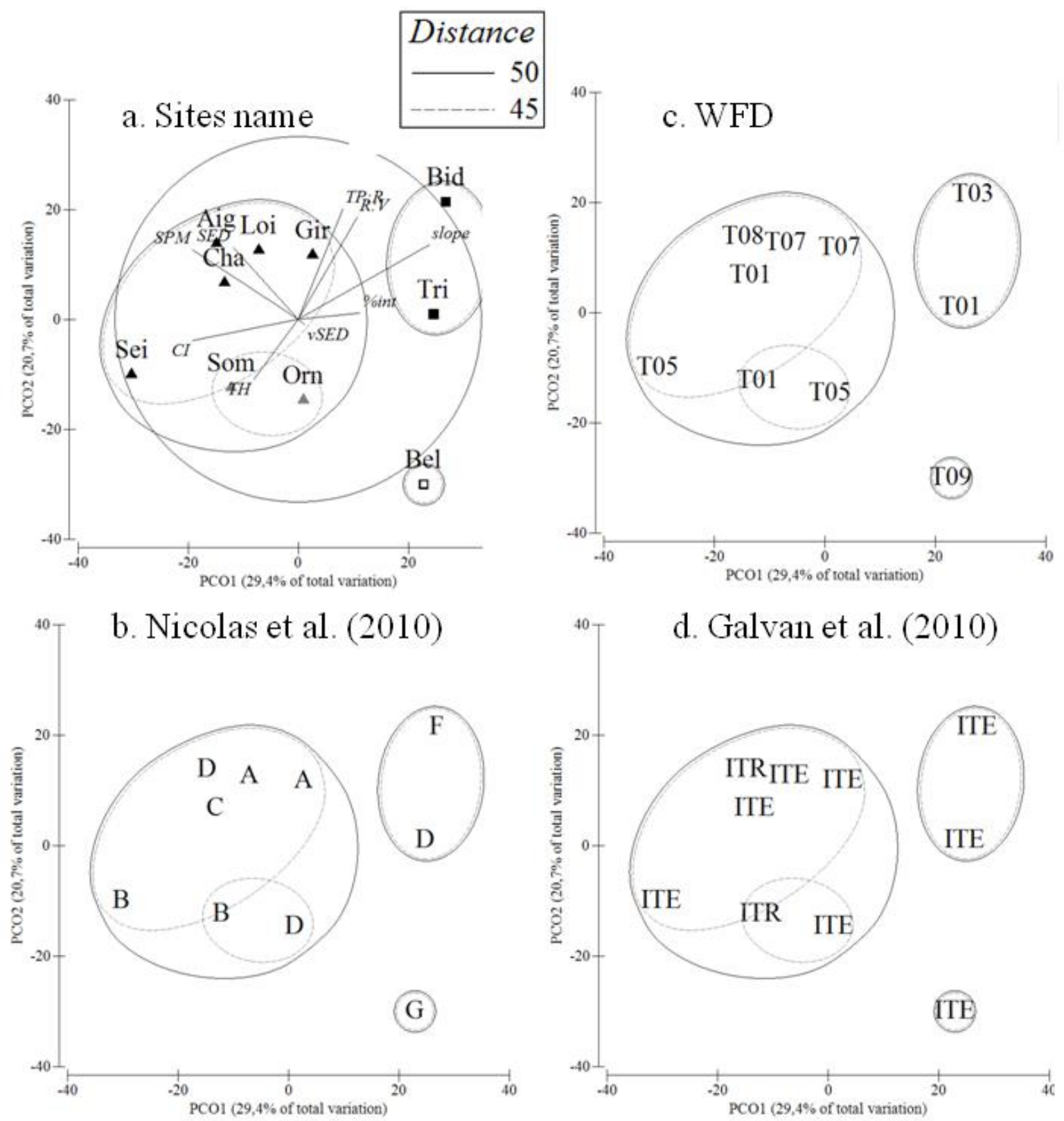

Fig 2 


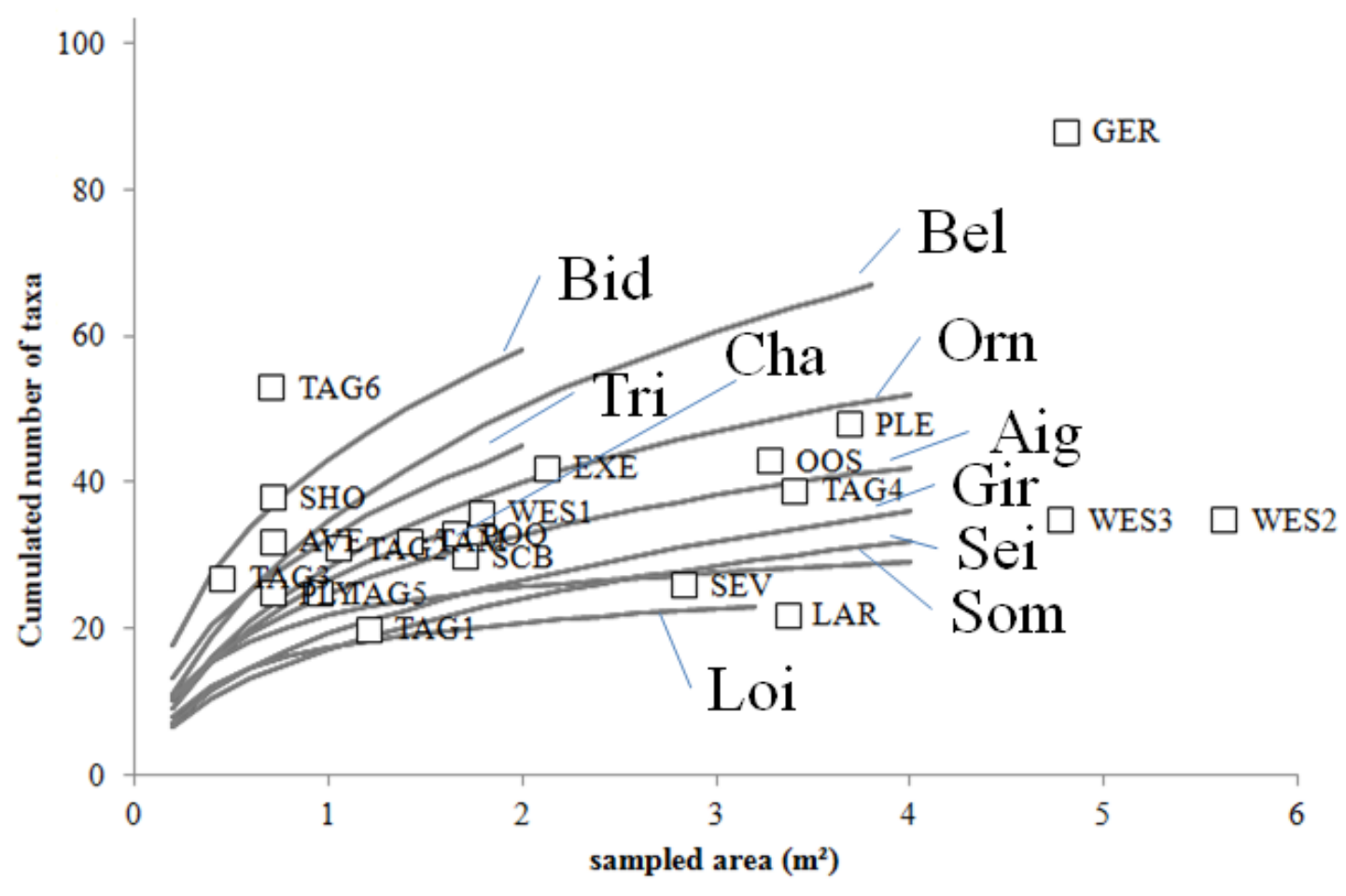

Fig 3 


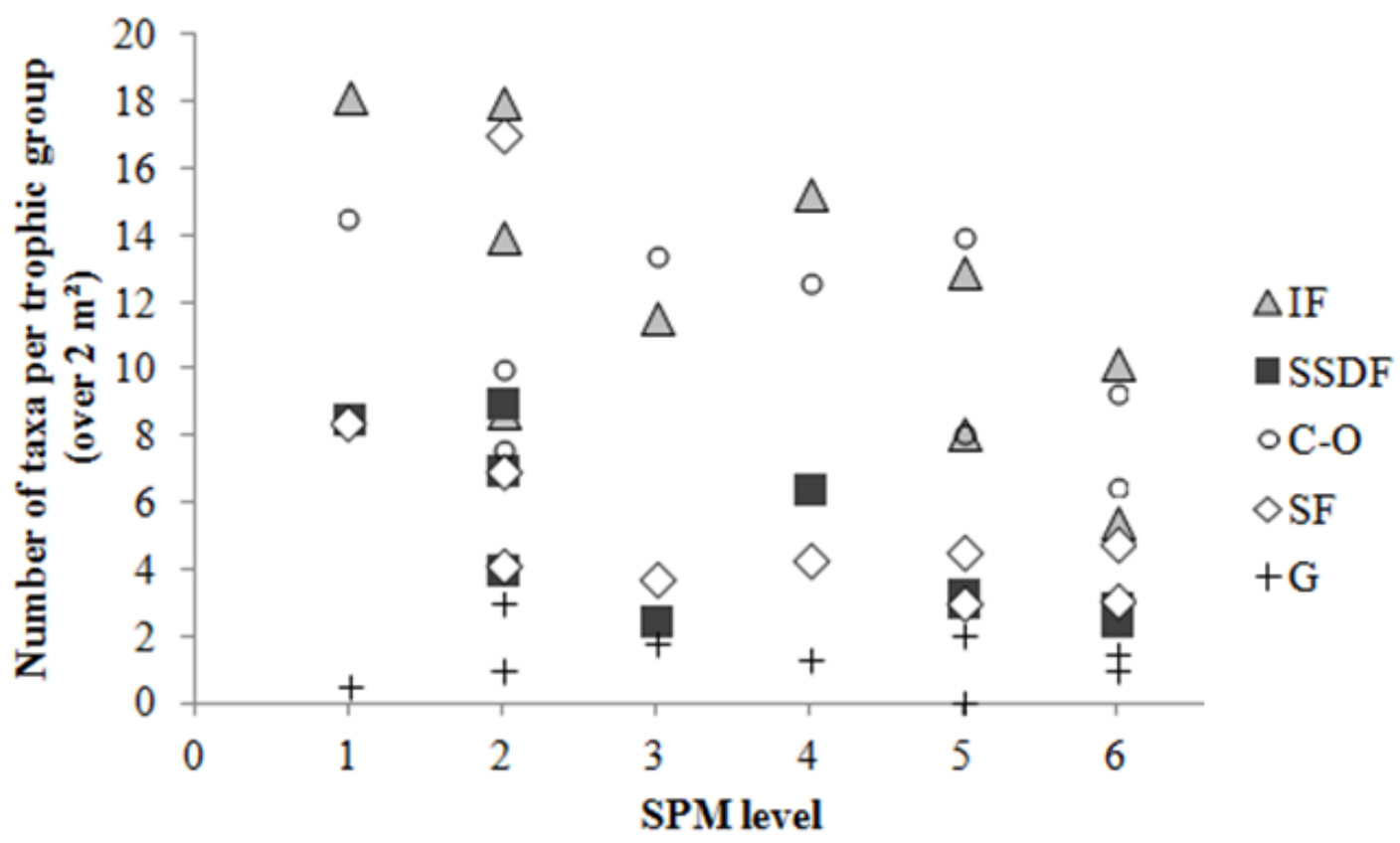

Fig 4 


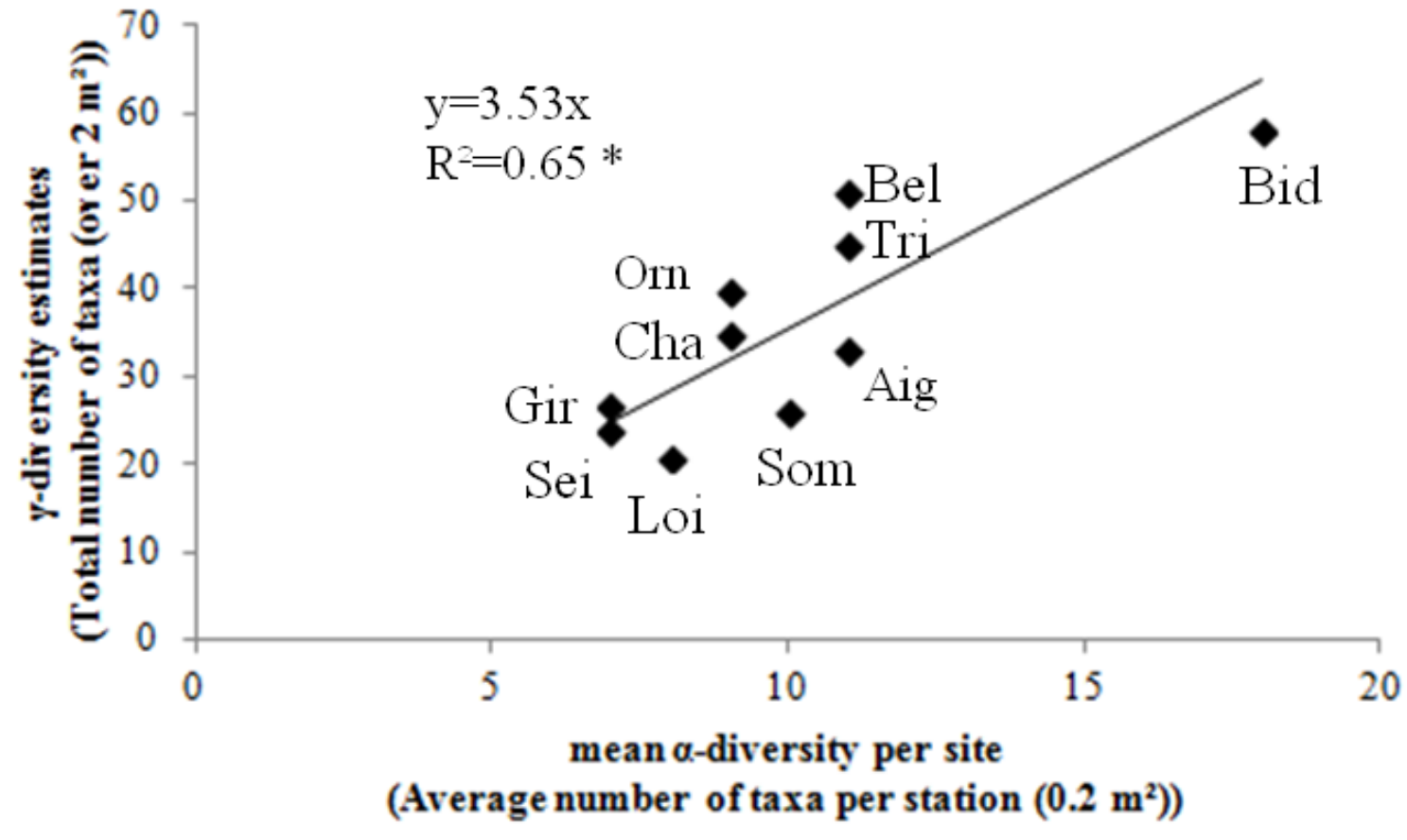

Fig 5 


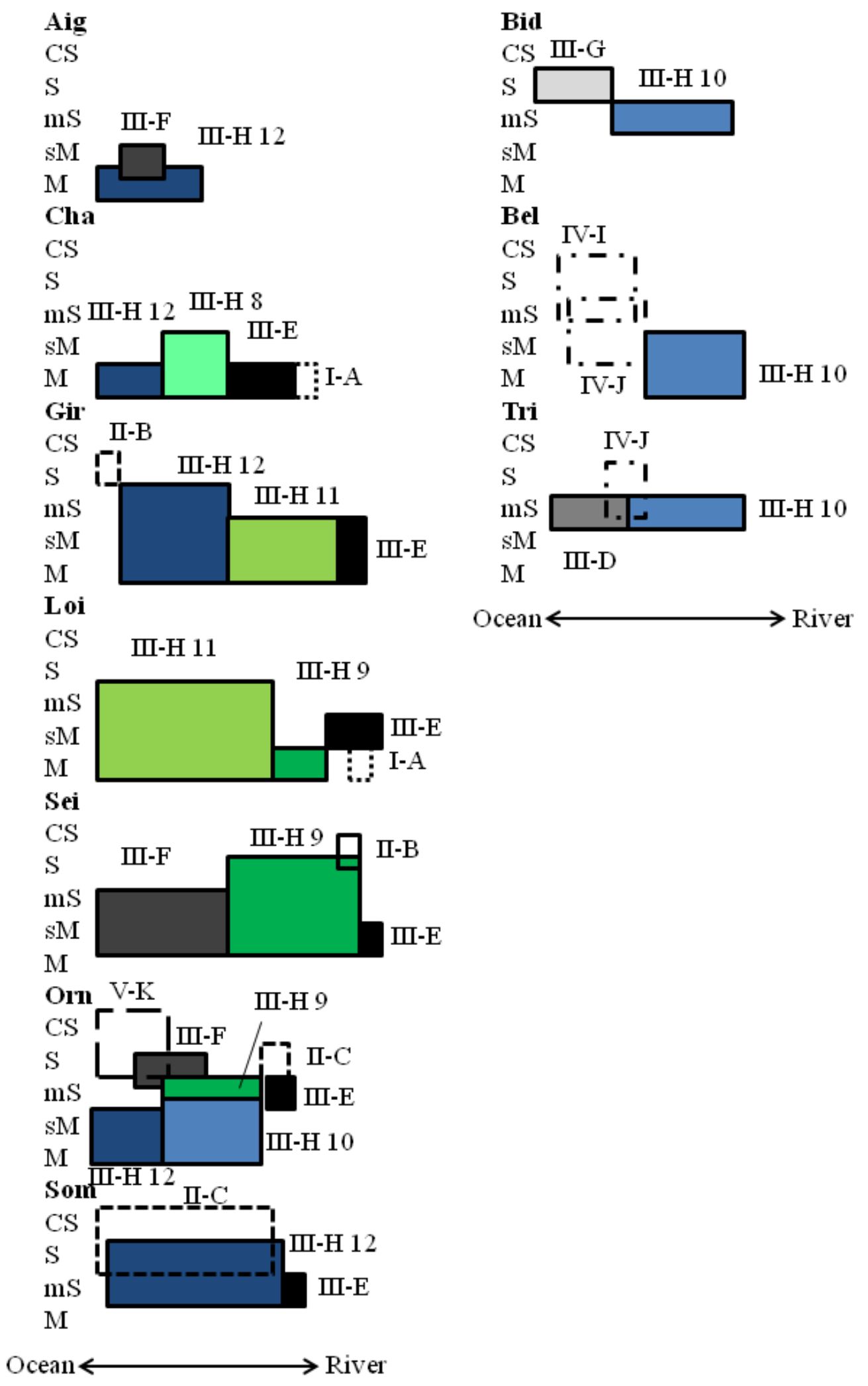

Fig 6 (color version) 


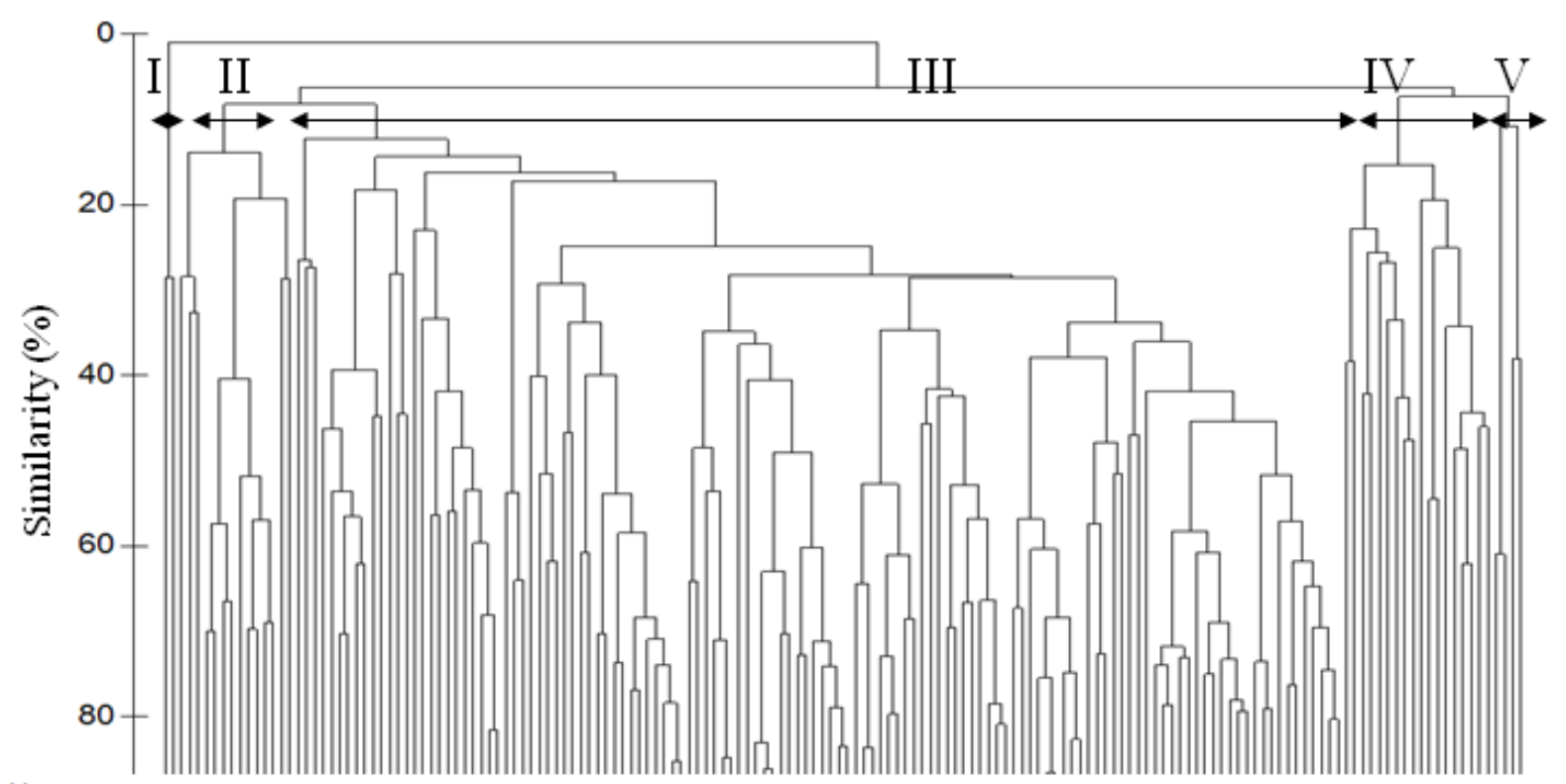

\begin{tabular}{|c|c|c|c|c|c|c|c|c|c|c|c|c|c|c|c|}
\hline \multirow{3}{*}{$\begin{array}{l}10 \% \\
20 \% \\
30 \% \\
\end{array}$} & I & \multicolumn{2}{|r|}{ II } & \multicolumn{9}{|c|}{ III } & \multicolumn{2}{|c|}{ IV } & \multirow{3}{*}{$\begin{array}{c}\mathrm{V} \\
\mathrm{K} \\
15\end{array}$} \\
\hline & A & B & $\mathrm{C}$ & D & E & $\mathrm{F}$ & G & & & $\mathrm{H}$ & & & I & $\mathrm{J}$ & \\
\hline & 1 & 2 & 3 & 4 & 5 & 6 & \begin{tabular}{|c|}
7 \\
\end{tabular} & 8 & 9 & 10 & 11 & 12 & 13 & 14 & \\
\hline sed. & $\mathrm{M} \mathrm{sM}$ & $\mathrm{s}$ & $S$ CS & $\mathrm{mS}$ & $\mathrm{M} \mathrm{sM} \mathrm{mS}$ & $\mathrm{MmS} \mathrm{S}$ & $\mathrm{s}$ & M sM & $\mathrm{M} \mathrm{sM} \mathrm{mS} \mathrm{S}$ & $\mathrm{sM} \mathrm{mS} \mathrm{S}$ & M $\mathrm{sM} \mathrm{mS}$ & $\mathrm{M} \mathrm{sMmS} \mathrm{S}$ & $\mathrm{mS} \quad \mathrm{CS}$ & $\mid \begin{array}{ll}\mathrm{mS} & \mathrm{CS}\end{array}$ & $\mathrm{s}$ cs \\
\hline Aig & & & & & & 2 & & & & & & $\begin{array}{ll}17 & 1 \\
\end{array}$ & & & \\
\hline Bel & & & & & & & & & & 11 & & & $\begin{array}{lll}3 & 4 & 2 \\
\end{array}$ & 52 & \\
\hline Bid & & & & & & & 3 & & & 61 & & & & & \\
\hline Cha & 1 & & & & 1 & & & 2 & & & & 4 & & & \\
\hline Gir & & 2 & & & 1 & & & 1 & & & 3 & $\begin{array}{lll}2 & 1 & 1 \\
\end{array}$ & & & \\
\hline Loi & 1 & & & & 3 & & & & 2 & & $\begin{array}{lll}1 & 5 & 4 \\
\end{array}$ & & & & \\
\hline $\mathrm{Om}$ & & & 1 & & 1 & 2 & & & 11 & $\begin{array}{lll}1 & 3 & 1 \\
\end{array}$ & & 23 & & & 2 \\
\hline Sei & & 1 & & & 1 & 16 & & & $\begin{array}{lll}2 & 6 \quad 3 \\
\end{array}$ & & & & & & \\
\hline Som & & & 9 & & & & & & & & & 36 & & & \\
\hline$\underline{\mathrm{In}}$ & & & & 3 & 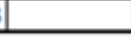 & & & & & 6 & & & & 1 & \\
\hline
\end{tabular}

\begin{tabular}{|c|c|c|c|c|c|c|c|c|c|c|c|c|c|c|c|}
\hline \multirow{4}{*}{\begin{tabular}{l|}
$10 \%$ \\
$20 \%$ \\
$30 \%$ \\
sed.
\end{tabular}} & \multirow{4}{*}{\begin{tabular}{|c|}
$\mathrm{I}$ \\
$\mathrm{A}$ \\
1 \\
$\mathrm{M} \mathrm{sM}$
\end{tabular}} & \multicolumn{2}{|r|}{ II } & \multicolumn{9}{|c|}{ III } & \multicolumn{2}{|r|}{ IV } & \multirow{3}{*}{\begin{tabular}{|c|}
$\mathrm{V}$ \\
$\mathrm{K}$ \\
15
\end{tabular}} \\
\hline & & B & $\mathrm{C}$ & D & E & F & G & & & $\mathrm{H}$ & & & I & $\mathrm{J}$ & \\
\hline & & 2 & 3 & 4 & 5 & 6 & \begin{tabular}{|l|}
7 \\
\end{tabular} & 8 & 9 & 10 & 11 & 12 & 13 & 14 & \\
\hline & & $\mathrm{s}$ & $S \mathrm{CS}$ & $\mathrm{mS}$ & $\mathrm{M} \mathrm{sM} \mathrm{mS}$ & $\mathrm{MmSS}$ & s & M s.M & M sM mS S & $\mathrm{sM} \mathrm{mS} \mathrm{S}$ & M sM mS : & $\mathrm{M} \mathrm{sM} \mathrm{mS} \mathrm{S}$ & $\mathrm{mS} \mathrm{S} \quad \mathrm{cs}$ & $\mathrm{mS} \mathrm{S} \mathrm{CS}$ & $\mathrm{s}$ cs \\
\hline Aig & & & & & & 32 & & & & & & $\begin{array}{|ll|}60 & 73 \\
\end{array}$ & & & \\
\hline Bel & & & & & & & & & & 0 & & & $\begin{array}{lll}45 & 78 & 70\end{array}$ & \begin{tabular}{l|lll}
0 & 36 & 80 & 78
\end{tabular} & \\
\hline Bid & & & & & & & 93 & & & 3461 & & & & & \\
\hline Cha & 11 & & & & 27 & & & $\begin{array}{|ll|}48 & 43 \\
\end{array}$ & & & & 89 & & & \\
\hline Gir & & 98 & & & $\begin{array}{|ll|}10 & 1 \\
\end{array}$ & & & 20 & & & $19 \quad 53$ & $\begin{array}{|lll|}67 & 88 & 68 \\
\end{array}$ & & & \\
\hline Loi & 25 & & & & \begin{tabular}{|l|}
36 \\
\end{tabular} & & & & 58 & & $\begin{array}{lll}100 & 78 & 80 \\
\end{array}$ & & & & \\
\hline $\mathrm{Om}$ & & & 30 & & 38 & 72 & & & $\begin{array}{lll}48 & 23 \\
\end{array}$ & $\begin{array}{lll}0 & 6 & 41 \\
\end{array}$ & & 6276 & & & $\begin{array}{ll}69 & 94 \\
\end{array}$ \\
\hline Sei & & 18 & & & 0 & $45 \quad 72$ & & & $\begin{array}{llll}20 & 26 & 13 \\
\end{array}$ & & & & & & \\
\hline Som & & & $57 \quad 86$ & & 17 & & & & & & & $41 \quad 78$ & & & \\
\hline $\mathrm{In}$ & & & & 86 & & & & & & 9 & & & & 42 & \\
\hline
\end{tabular}

Fig 7 

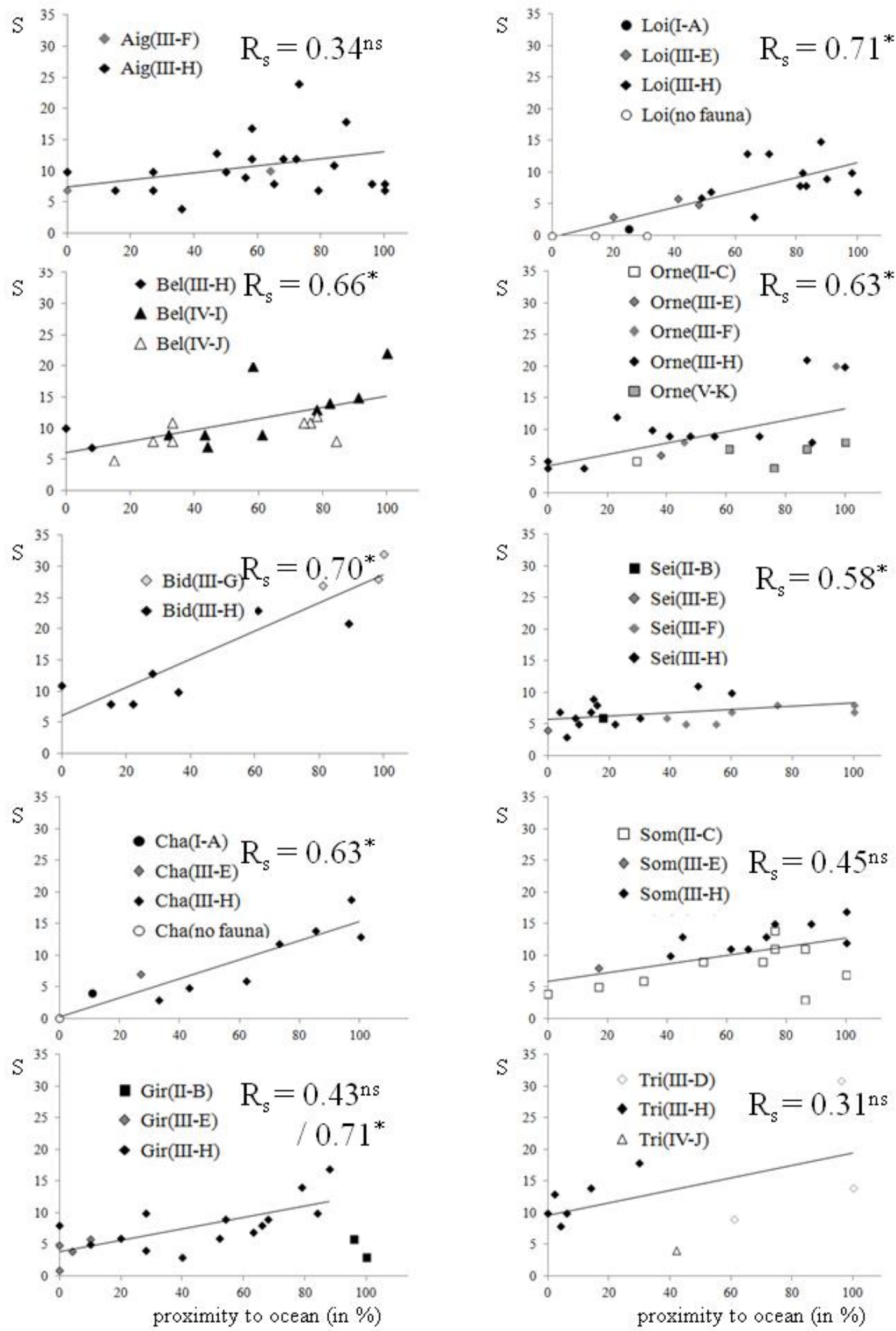

Fig 8 
Table 1: Main hydrological, morphogical and sedimentary characteristics of the ten studied sites. Sites are Aig: Aiguillon-Sèvre Niortaise, Bel: Belon, Bid: Bidassoa, Cha: Charente, Gir: Gironde, Loi: Loire, Orn: Orne, Sei: Seine, Som: Somme, Tri: Trieux. N: number of sampled stations, A: total area (in $\mathrm{km}^{2}$ ) and intertidal area (in brackets), TH: average tidal height (in $\mathrm{m}$ ), R: average yearly river discharge for the period October 2007-October $2008\left(\mathrm{~m}^{3} \cdot \mathrm{s}^{-1}\right)$, int: classes of relative intertidal area according to Nicolas et al. (2010) (1: 0-10\% intertidal; 2: 20-40\%; 3: 40-60\%; 4: 60-80\%; 5: 80100\%), TP:V: ratio between estimated tidal prism and estimated estuarine water volume at average high tide, R:V: ratio between the estimated volume of river inputs during a tidal cycle $(12 \mathrm{H})$ and estimated estuarine water volume at average high tide, CI : closure index (Hume et al., 2007) (low CI values correspond to more closed system while higher CI values correspond to more open systems), SED: median value of average sediment grain-size (in $\Phi$ unit), vSED: coefficient of variation of average sediment grain size (in \%), slope: average slope of the river-estuary system (in \%o), SPM: level of suspended particulate matter concentrations in water $\left(0: 0-5 \mathrm{mg} . \mathrm{L}^{-1} ; 1: 5-10 \mathrm{mg} . \mathrm{L}^{-1} ; 2: 10-50\right.$

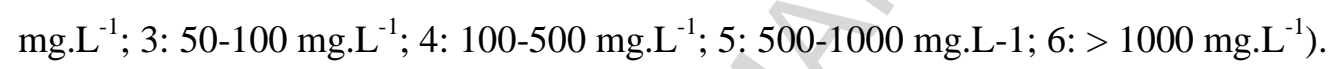

\begin{tabular}{|c|c|c|c|c|c|c|c|c|c|c|c|c|}
\hline Sites & $\mathrm{N}$ & A & $\mathrm{TH}$ & $\mathrm{R}$ & int & TP:V & $\mathrm{R}: \mathrm{V}$ & CI & SED & vSED & slope & SPM \\
\hline Aig & 20 & $\begin{array}{c}56.6 \\
(50.9)\end{array}$ & 5.7 & 20.3 & 5 & 0.98 & 0.003 & 0.10 & 6 & 0 & 0.9 & 3 \\
\hline Bel & 19 & $\begin{array}{c}2.8 \\
(1.7)\end{array}$ & 4.5 & 15 & 3 & 0.77 & 0.006 & 0.04 & 3.9 & 20 & 3.4 & 1 \\
\hline Bid & 10 & $\begin{array}{c}2.8 \\
(2.2)\end{array}$ & & 18 & 4 & 0.87 & 0.111 & 0.01 & 2.4 & 40 & 13 & 2 \\
\hline Cha & 10 & $\begin{array}{c}25.1 \\
(15.1)\end{array}$ & & 62.8 & 3 & 0.75 & 0.027 & 0.05 & 6 & 20 & 0.8 & 5 \\
\hline Gir & 20 & $\begin{array}{l}530 \\
(53)\end{array}$ & 5.1 & 960 & 1 & 0.47 & 0.028 & 0.06 & 5.7 & 20 & 4.5 & 6 \\
\hline Loi & 20 & $\begin{array}{l}239 \\
(96)\end{array}$ & 5.3 & 939 & 2 & 0.63 & 0.051 & 0.06 & 5.3 & 50 & 1.4 & 6 \\
\hline Orn & 20 & $\begin{array}{c}7.2 \\
(4.3)\end{array}$ & 7 & 27.5 & 3 & 0.81 & 0.03 & 0.06 & 3 & 50 & 2.3 & 4 \\
\hline Sei & 20 & $\begin{array}{l}198 \\
(20)\end{array}$ & 7.5 & 435 & 1 & 0.63 & 0.022 & 0.04 & 3.1 & 50 & 0.6 & 5 \\
\hline Som & 20 & $\begin{array}{c}40.5 \\
(36.0)\end{array}$ & 9 & 38 & 5 & 0.99 & 0.005 & 0.12 & 3 & 10 & 0.3 & 2 \\
\hline Tri & 10 & $\begin{array}{c}8.4 \\
(6.7) \\
\end{array}$ & 9.3 & 8.7 & 4 & 0.86 & 0.005 & 0.02 & 3.2 & 30 & 3.5 & 2 \\
\hline
\end{tabular}


Table 2: Spearman rank correlation coefficient $\left(R_{s}\right)$ among variables describing the hydromorphological features of the estuarine systems. TH: average tidal height (m), R: average river discharge $\left(\mathrm{m}^{3} \cdot \mathrm{s}^{-1}\right)$, A: area $\left(\mathrm{km}^{2}\right)$, int: proportion of intertidal area, TP:V: ratio between tidal prism and estuarine volume at high tide, $\mathrm{R}: \mathrm{V}$ : ratio between volume of freshwater discharged during one tidal cycle and estuarine volume at high tide, TP:R: ratio between tidal prism and volume of freshwater discharged into the estuarine system during one tidal cycle $(12 \mathrm{H})$, EE: estuary length, SC: complexity index, CI: closure index, SED: average grain size (in Phi-unit), vSED: variability of sediment grainsize, slope: average slope of the main rivers discharging into the estuary (ratio between river length and source elevation), SPM: suspended particulate matter level.

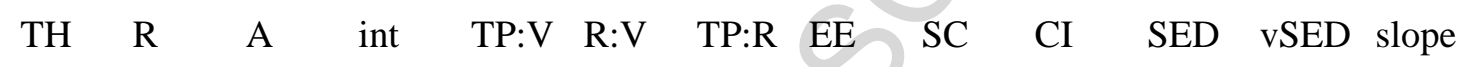

TH $\quad 0$

$\mathrm{R} \quad-0.24$

$\begin{array}{lll}\text { A } & -0.2 & 0.93\end{array}$

int $\quad 0.17 \quad-0.76-0.72$

$\begin{array}{lllll}\mathrm{TP}: \mathrm{V} & 0.32 & -0.85 & -0.83 & 0.95\end{array}$

$\begin{array}{llllll}\mathrm{R}: \mathrm{V} & -0.5 & -0.08 & -0.16 & 0.21 & 0.1\end{array}$

$\begin{array}{lllllll}\text { TP:R } & 0.41 & -0.43 & -0.31 & 0.66 & 0.68 & -0.47\end{array}$

$\begin{array}{llllllll}\mathrm{EE} & -0.23 & 0.49 & 0.39 & -0.68 & -0.71 & 0.35 & -0.95\end{array}$

$\begin{array}{lllllllll}\mathrm{SC} & 0.26 & -0.12 & -0.05 & 0.57 & 0.52 & -0.27 & 0.73 & -0.71\end{array}$

$\begin{array}{llllllllll}\text { CI } & 0.28 & 0.02 & 0.09 & 0.29 & 0.32 & -0.52 & 0.63 & -0.6 & 0.87\end{array}$

$\begin{array}{lllllllllll}\text { SED } & -0.32 & 0.51 & 0.51 & -0.25 & -0.38 & -0.35 & 0.13 & -0.02 & 0.05 & 0.28\end{array}$

$\begin{array}{llllllllllll}\text { vSED } & -0.02 & 0.3 & 0.07 & -0.51 & -0.41 & 0.38 & -0.77 & 0.73 & -0.65 & -0.56 & -0.35\end{array}$

$\begin{array}{lllllllllllll}\text { slope } & -0.5 & -0.09 & -0.07 & 0.2 & 0.03 & 0.49 & -0.4 & 0.32 & -0.28 & -0.62 & -0.36 & 0.21\end{array}$

$\begin{array}{llllllllllllll}\text { SPM } & -0.13 & 0.76 & 0.7 & -0.68 & -0.68 & -0.15 & -0.42 & 0.52 & -0.25 & 0.11 & 0.62 & 0.36 & -0.3\end{array}$ 
Table 3: List of the main taxa characterizing each assemblage according to the different levels of the hierarchical classification. The level of occurrence of each taxa within each assemblage (numbered from 1 to 15 ) is indicated by $* * *$ (taxa occurring in more than 2/3 of stations), ** (taxa occurring in more than $1 / 3$ of stations), * (taxa occurring in more than $1 / 5$ of stations), or - (taxa occurring in less than 1/5 of stations). Taxa identified as contributing together up to $70 \%$ to the within-group similarity are indicated in black, taxa which cumulative contribution to group similarity was lower than $70 \%$ but higher than $90 \%$ are indicated in grey. Taxa contributing together to more than $70 \%$ of within group similarity at a similarity level of $10 \%$ are underlined. These taxa were identified through the SIMPER procedure.

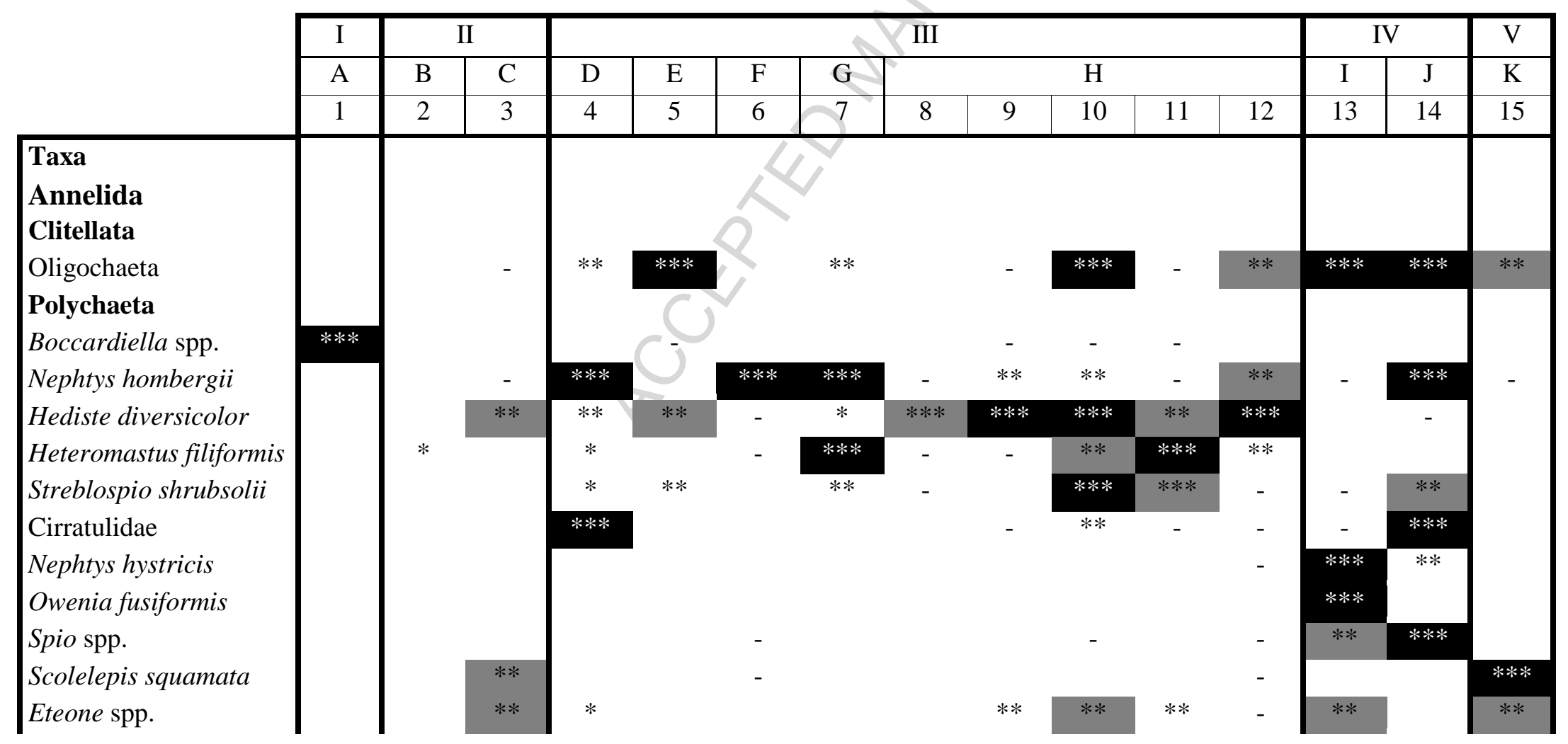


Capitella spp.

Melinna palmata

Ampharete sp.

Glycera convoluta

Pseudopolydora

paucibranchiata

Nephtys cirrosa

Alkmaria romijni

Pygospio elegans

Phyllodoce spp.

Pseudopolydora

antennata

Paradoneis spp.

Phylo foetida

Notomastus latericeus

Capitomastus minima

Arenicola marina

Ophelia rathkei

Crustacea

Amphipoda

Haustorius arenarius

Bathyporeia sarsi

Bathyporeia pilosa

Bathyporeia elegans

Corophium volutator

Corophium

acherusicum

Decapoda

Crangon crangon

Isopoda

Cyathura carinata
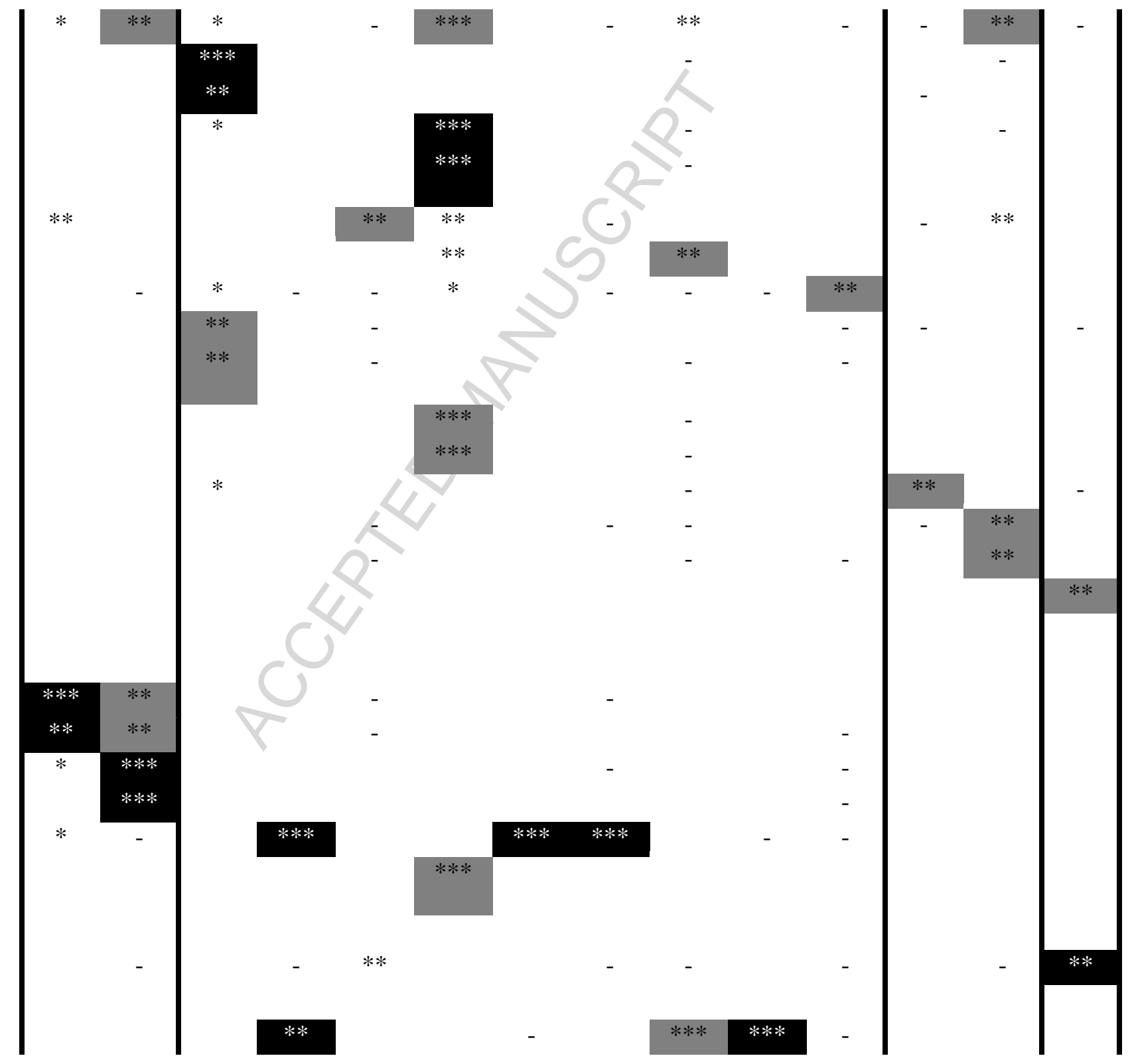


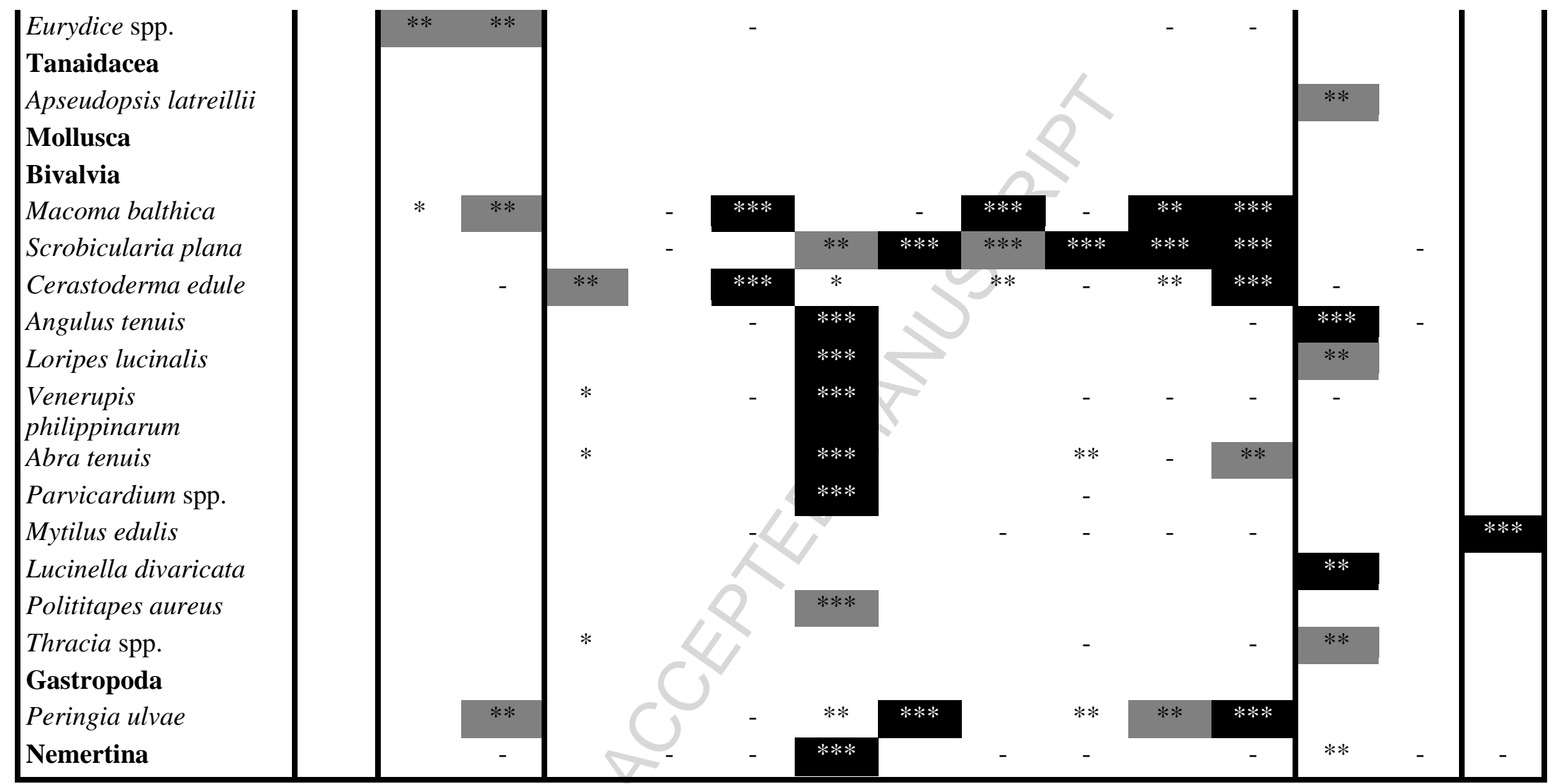


Table 4: Percentage of variation in Bray-Curtis similarity explained by variations in distance to ocean (\% downstream), variations in grain-size and combination of both variables (Combined) as estimated by the DISTLM procedure. The level of correlation between both variables is given. Significant contributions $(\mathrm{p}<0.05)$ are indicated by *. For combinations, increase of explained variation higher than $10 \%$ are indicated in brakets.

$$
\% \text { downstream Grain-size Combined correlation }
$$

Within sites

\begin{tabular}{|c|c|c|c|c|}
\hline Aiguillon & $8 \%{ }^{\mathrm{ns}}$ & $15 \% *$ & $19 \%{ }^{\mathrm{ns}}$ & -0.35 \\
\hline Belon & $15 \% *$ & $10 \%$ & $19 \%$ ns & -0.47 \\
\hline Bidassoa & $56 \% *$ & $13 \%$ ns & $56 \% *$ & -0.45 \\
\hline Charente & $42 \% *$ & $9 \% n s$ & $52 \% *$ & -0.08 \\
\hline Gironde & $17 \% *$ & $17 \% *$ & $35 \% *(+18)$ & -0.64 \\
\hline Loire & $34 \% *$ & $10 \%$ ns & $43 \%$ ns & -0.17 \\
\hline Orne & $12 \% *$ & $21 \% *$ & $31 \% *(+10)$ & -0.20 \\
\hline Seine & $41 \% *$ & $23 \% *$ & $56 \% *(+15)$ & -0.37 \\
\hline Somme & $10 \%$ ns & $14 \% *$ & $25 \% *$ & -0.15 \\
\hline Trieux & & $25 \% *$ & $48 \% *(+18)$ & -0.36 \\
\hline \multicolumn{5}{|l|}{ Within Assemblage III } \\
\hline Bidassoa (H \& G) & $56 \% *$ & $13 \%{ }^{\mathrm{ns}}$ & $57 \% *$ & -0.45 \\
\hline Charente (H \& E) & $44 \% *$ & $<1 \%$ ns & $52 \% *$ & +0.07 \\
\hline Gironde (H \& E) & $23 \% *$ & $<1 \%{ }^{\mathrm{ns}}$ & $24 \% *$ & -0.47 \\
\hline Loire (H \& E) & $37 \% *$ & $12 \%^{\mathrm{ns}}$ & $49 \% *$ & -0.11 \\
\hline Orne (H, F, E) & $20 \% *$ & $18 \% *$ & $37 \% *(+17)$ & -0.09 \\
\hline Seine $(H, F, E)$ & $46 \% *$ & $25 \% *$ & $60 \% *(+14)$ & -0.40 \\
\hline Trieux (H \& D) & $38 \% *$ & $12 \% *$ & $54 \% *(+16)$ & -0.41 \\
\hline \multicolumn{5}{|l|}{ Within Assemblage $H$} \\
\hline Charente (H12 \& H8) & $57 \% *$ & $13 \%{ }^{\mathrm{ns}}$ & $65 \% *$ & +0.28 \\
\hline Gironde (H12, H11, H8) & $27 \% *$ & $<1 \%{ }^{\mathrm{ns}}$ & $30 \% *$ & -0.48 \\
\hline Loire (H11 \& H9) & $20 \% *$ & $17 \% *$ & $37 \% *(+17)$ & -0.09 \\
\hline Orne (H12, H10, H9) & $23 \% *$ & $16 \% *$ & $39 \% *(+16)$ & +0.09 \\
\hline
\end{tabular}

